\title{
Transcriptome Profile Analysis of Triple-Negative Breast Cancer Cells in Response to a Novel Cytostatic Tetrahydroisoquinoline Compared to Paclitaxel
}

\author{
Madhavi Gangapuram (D), Elizabeth A. Mazzio, Kinfe K. Redda *(D) and Karam F. A. Soliman *(D)
}

check for updates

Citation: Gangapuram, M.; Mazzio, E.A.; Redda, K.K.; Soliman, K.F.A. Transcriptome Profile Analysis of Triple-Negative Breast Cancer Cells in Response to a Novel Cytostatic Tetrahydroisoquinoline Compared to Paclitaxel. Int. J. Mol. Sci. 2021, 22, 7694. https://doi.org/10.3390/ ijms22147694

Academic Editor: Antonella Zannetti

Received: 24 May 2021

Accepted: 16 July 2021

Published: 19 July 2021

Publisher's Note: MDPI stays neutral with regard to jurisdictional claims in published maps and institutional affiliations.

Copyright: (c) 2021 by the authors. Licensee MDPI, Basel, Switzerland. This article is an open access article distributed under the terms and conditions of the Creative Commons Attribution (CC BY) license (https:// creativecommons.org/licenses/by/ $4.0 /)$.
Pharmaceutical Sciences Division, College of Pharmacy \& Pharmaceutical Sciences, Institute of Public Health, Florida A\&M University, Tallahassee, FL 32307, USA; madhavi.gangapuram@famu.edu (M.G.); elizabeth.mazzio@famu.edu (E.A.M.)

* Correspondence: kinfe.redda@famu.edu (K.K.R.); karam.soliman@famu.edu (K.F.A.S.)

\begin{abstract}
The absence of chemotherapeutic target hormone receptors in breast cancer is descriptive of the commonly known triple-negative breast cancer (TNBC) subtype. TNBC remains one of the most aggressive invasive breast cancers, with the highest mortality rates in African American women. Therefore, new drug therapies are continually being explored. Microtubule-targeting agents such as paclitaxel (Taxol) interfere with microtubules dynamics, induce mitotic arrest, and remain a first-inclass adjunct drug to treat TNBC. Recently, we synthesized a series of small molecules of substituted tetrahydroisoquinolines (THIQs). The lead compound of this series, with the most potent cytostatic effect, was identified as 4-Ethyl-N-(7-hydroxy-3,4-dihydroisoquinolin-2(1H)-yl) benzamide (GM-453). In our previous work, GM-4-53 was similar to paclitaxel in its capacity to completely abrogate cell cycle in MDA-MB-231 TNBC cells, with the former not impairing tubulin depolymerization. Given that GM-4-53 is a cytostatic agent, and little is known about its mechanism of action, here, we elucidate differences and similarities to paclitaxel by evaluating whole-transcriptome microarray data in MDAMB-231 cells. The data obtained show that both drugs were cytostatic at non-toxic concentrations and caused deformed morphological cytoskeletal enlargement in 2D cultures. In 3D cultures, the data show greater core penetration, observed by GM-4-53, than paclitaxel. In concentrations where the drugs entirely blocked the cell cycle, the transcriptome profile of the 48,226 genes analyzed (selection criteria: ( $p$-value, FDR $p$-value $<0.05$, fold change $-2<$ and $>2$ )), paclitaxel evoked 153 differentially expressed genes (DEGs), GM-4-53 evoked 243 DEGs, and, of these changes, 52/153 paclitaxel DEGs were also observed by GM-4-53, constituting a 34\% overlap. The 52 DEGS analysis by String database indicates that these changes involve transcripts that influence microtubule spindle formation, chromosome segregation, mitosis/cell cycle, and transforming growth factor- $\beta$ (TGF- $\beta$ ) signaling. Of interest, both drugs effectively downregulated "inhibitor of DNA binding, dominant negative helix-loop-helix" (ID) transcripts; ID1, ID3 and ID4, and amphiregulin (AREG) and epiregulin (EREG) transcripts, which play a formidable role in cell division. Given the efficient solubility of GM-4-53, its low molecular weight (MW; 296), and capacity to penetrate a small solid tumor mass and effectively block the cell cycle, this drug may have future therapeutic value in treating TNBC or other cancers. Future studies will be required to evaluate this drug in preclinical models.
\end{abstract}

Keywords: drug discovery; cytostatic; cancer

\section{Introduction}

Breast cancer continues to be a major public health concern, particularly the subclass referred to as "triple-negative breast cancer" (TNBC). TNBC is characterized by an absence of endocrine chemotherapy receptor targets, fewer treatment options, and greater occurrence in premenopausal and African American women (AAW) [1]. In AAW, TNBC is typically associated with advanced-stage diagnosis, shorter disease-free survival, a proclivity toward distant bone metastasis, and higher mortality than non-TNBC breast cancers [2,3]. Standard 
treatments for TNBC include the combined use of cytotoxic and cytostatic agents; taxanes (docetaxel and paclitaxel), anthracyclines (doxorubicin and epirubicin), cyclophosphamide, fluorouracil, capecitabine, or platinum-based drugs $[4,5]$. Taxanes mediate cytostatic effects by holding the cytoskeletal architecture static. The cytoskeleton is made up of microtubules (alpha- and beta-heterodimers), where paclitaxel binds to tubulin and disrupts the dynamics of polymerization and depolymerization, which otherwise required for microtubule treadmilling and mitosis. Most of the research on taxanes explores how they mediate effects on tubulin dynamics rather than how they alter the cancer transcriptome, except for eventual drug resistance. However, cancer itself is a disease mired in pathological genetic alteration, which results in rampant cell proliferation.

Breast cancer is pathologically demarcated by a plethora of abnormal gene profiles and transcripts that drive tumor initiation (MYC, Erb-B2 Receptor tyrosine kinase 2 (ERBB2) [6,7], tumor progression (FOS, JUNB) [8], proliferation and metastasis (epidermal growth factor receptor (EGRF)) $[9,10]$. These changes are worsened by the concurrent loss of tumor suppressors (transcription factor p53, E-cadherin) [6,11] and global defects in DNA repair mechanisms (e.g., phosphatidylinositol 3,4,5-trisphosphate 3-phosphatase and dual-specificity protein phosphatase (PTEN), retinoblastoma protein 1 (RB1) and breast-cancer-associated (BRCA) 1,2 genes) [12-14].

The TNBC sub-class contains a confounding underlying pathological gene profile with a greater propensity for epithelial-to-mesenchymal transition (EMT), rapid cell proliferation (cyclin-dependent kinase inhibitor 1A (P21), PI3K/Akt, Wnt/beta-catenin signaling), and stem cell differentiation (S-100, p63, or vimentin), with most, if not all, abnormalities associated with underlying changes in epigenetic architecture [15-20]. Even worse, once TNBC malignancy is established, tertiary pathological gene profiles can arise from the treatments themselves, leading to lethal chemo- and radiation-resistant cancer. These include changes in gene expression profiles for chemokine and leukocyte recruitment peptides (PTGS2, IL-6, CCL2, CXCL8, and CXCL12) [21,22] those that drive angiogenesis (ANGPT1, VEGFA), cell-cycle progression proteins (EGR1, MYC, FOS, CDKN1A, CA2, ANKRD46) and those involved with multidrug resistance [15,21,23-25]. Chemoresistant tumors are circumscribed by advanced tumor-promoting pathways involving JAK/STAT3, [26] HSPC154, PI3KAkt, [27,28] CYP1A1, TNF [29], TAZ-TEAD-Cyr61/CTGF [30], folate receptor 1 signaling (FOLR1) [31] and overexpression of paclitaxel resistance-associated genes (TRAGs), with many, if not all, being associated with underlying epigenetic-controlling elements [21,32]. The latter involves individual silenced hyper-methylated and hypo-methylated promoter regions of influential genes [33], and a fluctuation in miRNAs (e.g., miR-634), and/or circular RNAs (circRNAs) [34,35]. Even though mainline drugs used to treat TNBC, such as paclitaxel, in combination with anthracyclines, are largely effective, there are still limitations including side effects, chemoresistance, solubility, and delivery, with efforts being made to improve formulations or delivery systems [36].

Due to the great need for novel drug development in the area of TNBC, we synthesized a novel cytostatic compound; GM-4-53 (Figure 1), with similarities to paclitaxel in terms of therapeutic effect, without the well-known tubulin polymerization and thwarted retraction and treadmilling actions of the latter, which are the primary mechanism behind abrogated mitosis [37-40]. In this work, we further examine how paclitaxel and GM-4-53 affect the transcriptome of TNBC, to elucidate a plausible mechanism of action underpinning cytostatic effects [41]. 


\begin{tabular}{|c|c|c|}
\hline CODE & STRUCTURE & MW \\
\hline 4-Ethyl- $N$-(7-hydroxy-3,4-dihydroisoquinolin- \\
2(1H)-yl) benzamide
\end{tabular}

Figure 1. Chemical Structure of GM-4-53.

\section{Results}

The anti-proliferative inhibitory growth $\left(\mathrm{IG}_{50 \mathrm{~s}}\right)$ was calculated by regression analysis from data acquired in a prolonged 6-day study, GM-4-53 (Figure 2A) and paclitaxel (Figure 2B). To establish that cell toxicity was not an interfering variable for both drugs, we conducted a 36-h toxicity assay over identical dose concentrations ranges at a higher plating density $0.5 \times 10^{5}$ cells/well (data not shown), where no cytotoxic effects were found. Optimal concentrations for whole-transcriptomic (WT) microarray analysis were selected as $1 \mu \mathrm{g} / \mathrm{mL}$ for paclitaxel, and $5 \mu \mathrm{g} / \mathrm{mL}$ for GM-4-53, to establish a complete cell cycle blockade without cytotoxic effects, and a 36-h time point was chosen for endpoint analysis to elucidate changes at the gene transcript levels. The altered cytoskeletal changes evident at the 6-day endpoint are reflected in Figure 3, stained with phalloidin (actin) and propidium iodide (nuclear counterstain) in fixed permeabilized cells. The $10 \times$ images reflect the proliferation rate vs. controls, corresponding to the data in Figure 2A,B, where the $25 \times$ images show a zoom in on the gross abnormalities in cytoskeletal architecture evoked by both cytostatic agents. Furthermore, cell proliferation using comparative human female cancer cell lines was carried out by the Southern Research Institute, where the $\mathrm{IG}_{50} \mathrm{~s}$ are presented in Table 1, showing efficacy in the mid-to-high $n \mathrm{M}$ range by GM-4-53 in diverse females cancer cell lines.

A summary view of significant DEG counts according to fold change, and significance (volcano plot) elicited by both drugs are presented in Figure 4. Specifics of these gene changes are presented in Figure 5, and the full data files can be found in Supplementary Table S1 file, which lists gene symbol, gene description, average Log2 (signals) fold change (FC), $p$-Value, and false discovery rate (FDR). Table S1 contains information on each individual drug vs. control. Figure 5 summary shows that GM-4-53 evoke 75 upregulated DEGs vs. controls, 168 down-regulated DEGs vs. controls; paclitaxel evoked 108 upregulated DEGS vs. controls and 45 down-regulated DEGs vs. controls, with 52 of these genes being shared by both drugs. Of the 45 genes down-regulated by paclitaxel, 29 of these were also observed by GM-4-53, which constitutes a $64 \%$ overlap. 
A
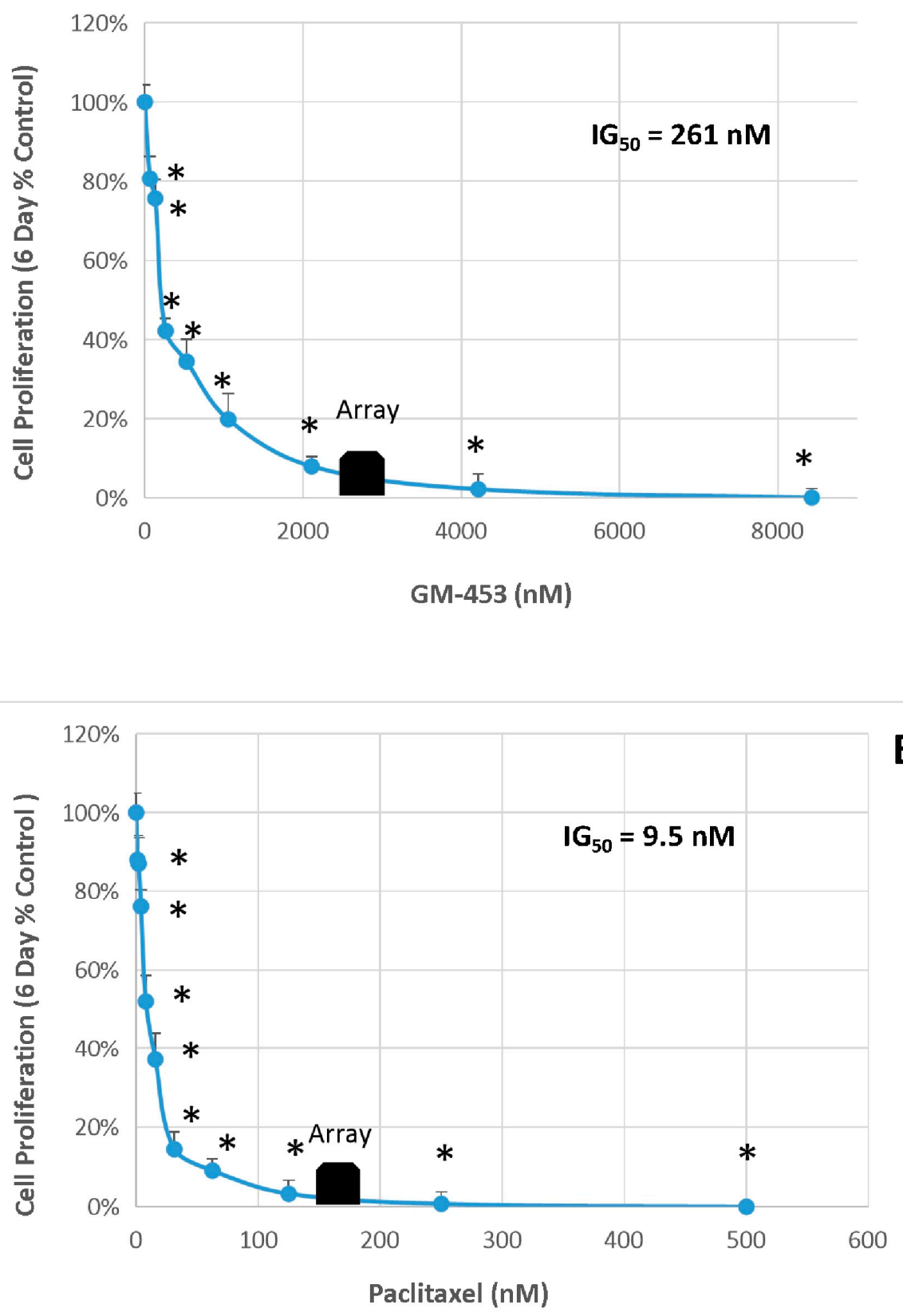

B

Figure 2. Cytostatic growth-inhibitory effects of GM-4-53 (A) and paclitaxel (B) in MDA-MB-231 cells were determined with an endpoint cell count analysis conducted on day 6 . The data represent cell count/proliferation (as \% untreated control) and are expressed as the Mean \pm SEM, with the $\mathrm{IG}_{50} \mathrm{~s}$ determined by regression analysis. Significant differences from the control were determined using a one-way ANOVA followed by a Tukey post hoc test. ${ }^{*} p<0.05$. Array blocks denote the specific concentrations used for microarray analysis vs. controls. 


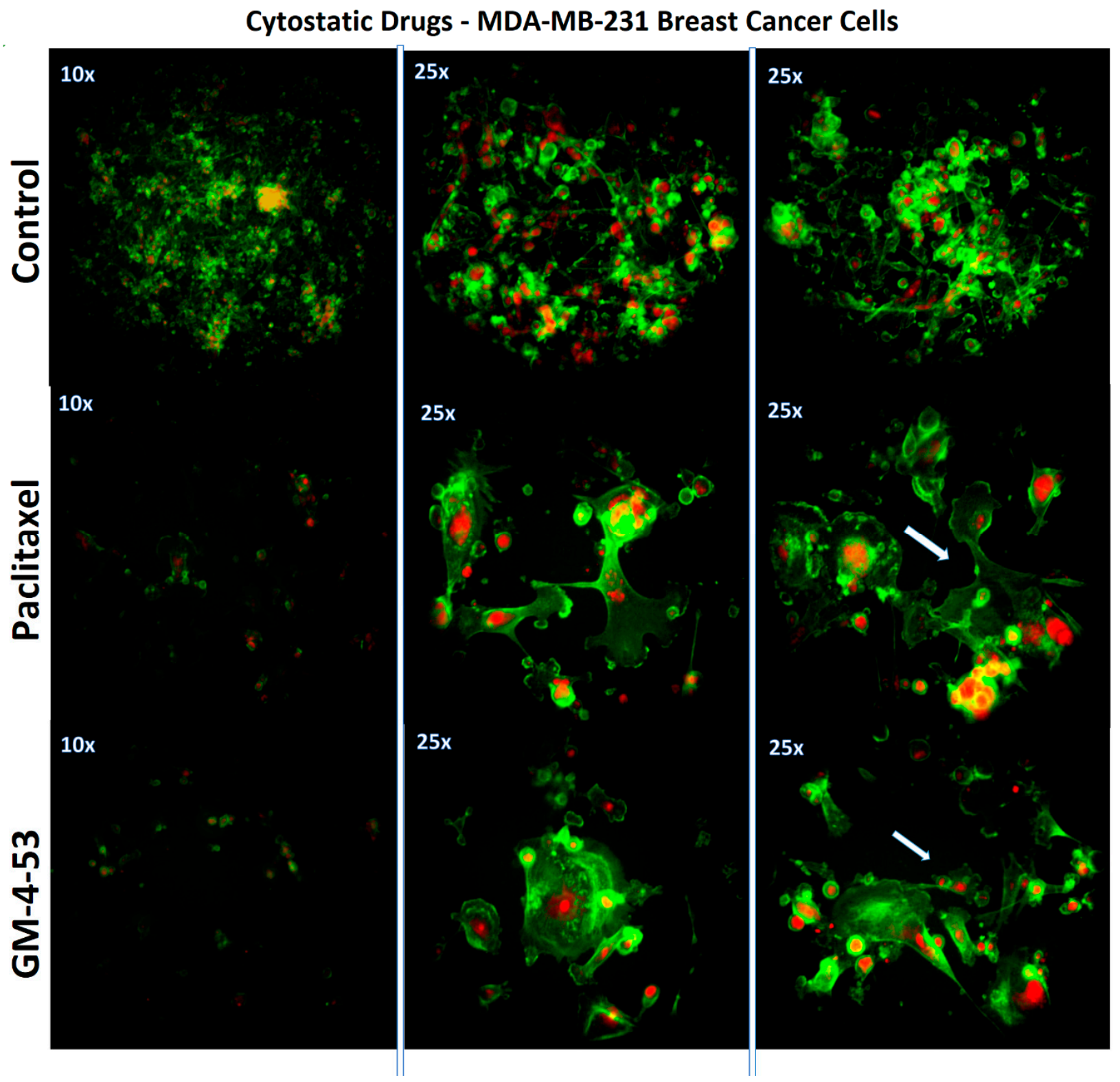

Figure 3. Morphological Changes associated with cytostatic growth-inhibitory effects by GM-4-53 $5 \mu \mathrm{g} / \mathrm{mL}$ and paclitaxel $1 \mu \mathrm{g} / \mathrm{mL}$ in MDA-MB-231 cells evaluated at day 6 . The images demonstrate cytostatic changes to the actin cytoskeletal architecture (green) with a propidium iodide nuclear counterstain (red) in the presence of either drug vs. untreated controls. $[10 \times]$ shows the basic overview of accumulated cell number (cell proliferation), where [25 $\times$ ] shows higher magnification to enable visualization of deformed cell morphology $n=2$. The images show abnormally large-shaped extended actin networks in cells that are unable to divide.

Table 1. Variable cell line: cytostatic growth-inhibitory effects of GM-4-53 in Ishikawa, MCF-7 vs. MDA-MB-231 cells were determined by regression analysis. The data show a consistent cytostatic effect in diverse female cancers in the mid-to-high nM range.

\begin{tabular}{cccc}
\hline & MCF-7 & Ishikawa & MDA-MB-231 \\
\hline & Human Breast Cancer & Human Endometrial & Human Breast Cancer \\
(ER+, PR+) & Cancer & (TNBC) (ER_) (PR_) \\
\hline GM-4-53 & IG50 (nM) & IG50 (nM) & IG50 (nM) \\
\hline
\end{tabular}



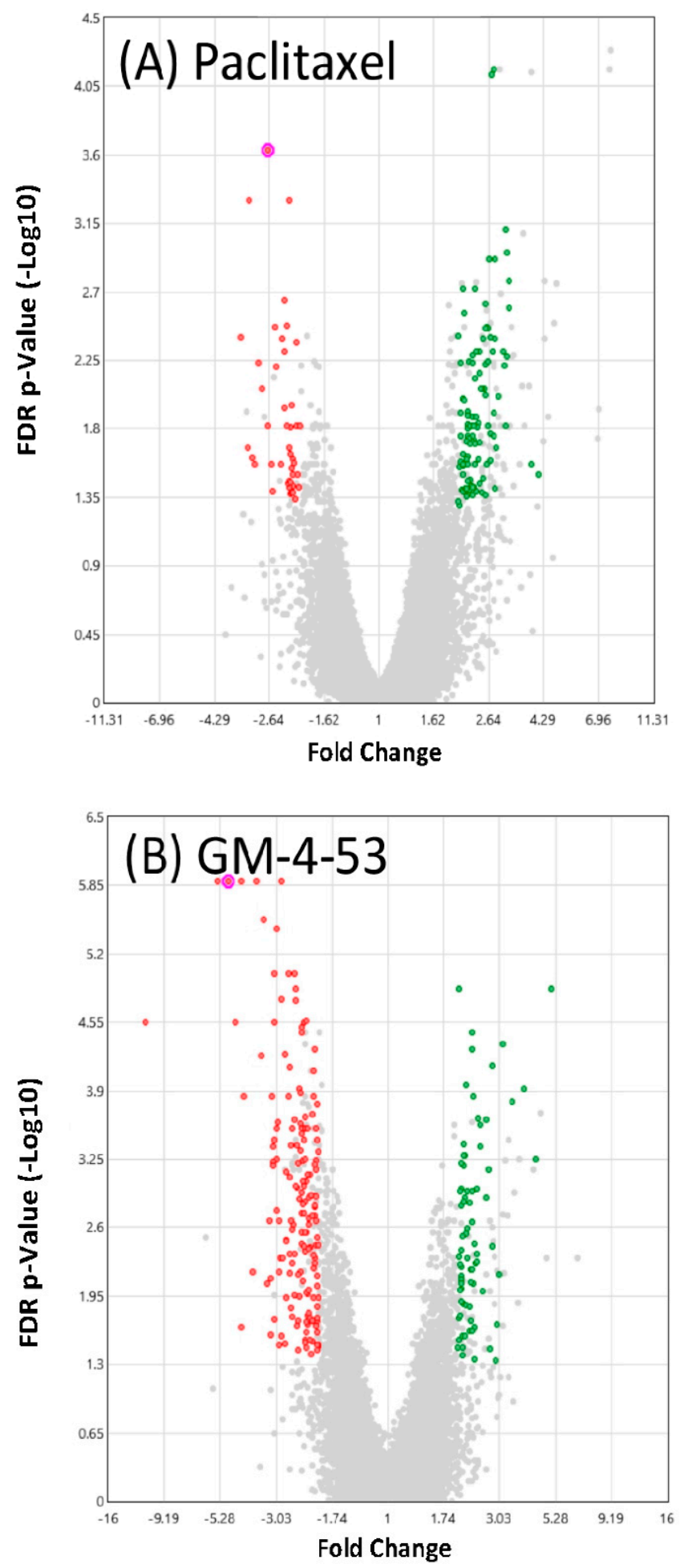

Figure 4. Summary of gene changes by fold change and significance in cytostatic cells vs. untreated controls from a total of 48,226 genes analyzed. (A) paclitaxel $(1 \mu \mathrm{g} / \mathrm{mL})$ vs. controls (B) GM 4-53 $(5 \mu \mathrm{g} / \mathrm{mL})$ in MDA-MB-231. The data show upregulated DEGs (right/green) and downregulated DEGs (left/red) by fold change relative to untreated controls ( $X$-axis), with FDR $p$-values ( $Y$-axis). Selected criteria for array analysis: Fold change $>2$ or $<-2, p$-value $<0.05$, and false discovery rate (FDR) $p$-value $<0.05$. Plotted points denoted in gray did not meet the selected criteria. 


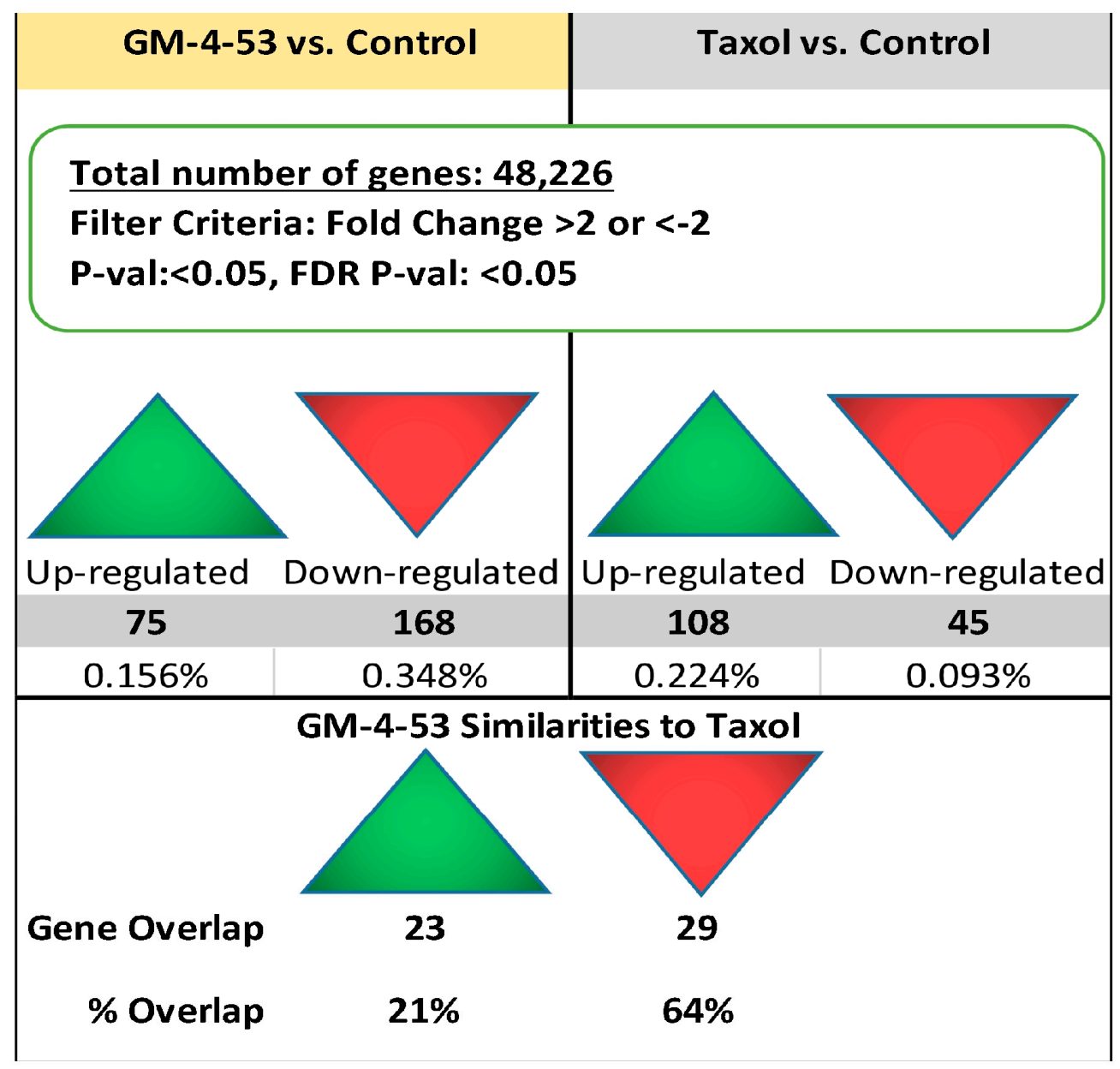

Figure 5. Gene Summary Report. Overall summary of DEGs reflected by whole-transcriptomic analysis in GM-4-53 (5 $\mathrm{g} / \mathrm{mL})$ - or Paclitaxel $(1 \mu \mathrm{g} / \mathrm{mL})$-treated cells vs. controls after $36 \mathrm{~h}$ of incubation in MDA-MB-231 cells; Criteria $=$ FC $>2$ or $<-2, p$-Value $<0.05$ and FDR $p$-value $<0.05$. Information on overlapping DEGs common to paclitaxel and GM-4-53 are also displayed. The gene summary data for each DEG, along with gene symbol, description, fold change, and significance, are presented in Supplementary Table S1.

Using STRING/Protein-Protein Functional Enrichment Analysis, we further examine the 52 DEG overlap evoked by both paclitaxel and GM-4-53. (Figure 6) The data show both drug target genes having a primary molecular classification impact on spindle microtubules, chromosomal segregation, spindle microtubules to the kinetochore, TGF-beta signaling, and the MAPK signaling pathway. The 52-gene overlap, using a plotted fold overlay (Figure 7), shows the magnitude (FC) and direction (up/down) of these particular DEGs to be closely aligned; some of these are listed in Table 2. 


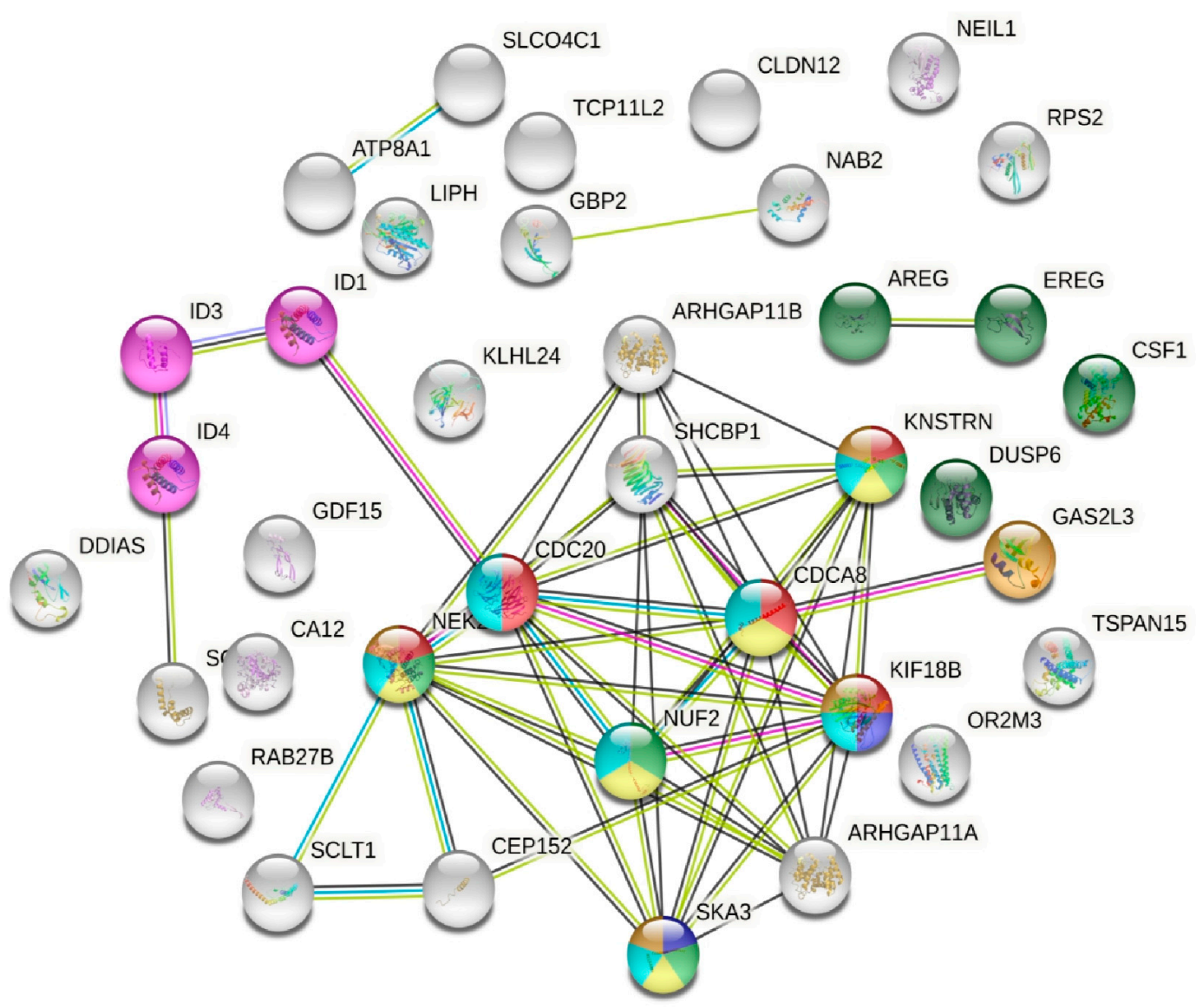

\section{Overlapping DEGs by GM-4-53 and Taxol}

\begin{tabular}{|c|c|c|c|c|c|c|}
\hline ID & Go-Term & Description & $\begin{array}{l}\text { Count in } \\
\text { Network }\end{array}$ & Strength & FDR & Color Code \\
\hline & \multicolumn{6}{|c|}{ Biological Process } \\
\hline Go Term & GO:0000070 & Mitotic Sister Chromatid Segregation & 5 or 110 & 1.42 & $1.1 \times 10-3$ & \\
\hline \multirow[t]{2}{*}{ Go Term } & GO:0051988 & Spind le Microtu bu les to Kinectochore & 2 of 12 & 1.95 & $1.8 \times 10-2$ & \\
\hline & \multicolumn{6}{|c|}{ Cellular Component (Gene Ontology) } \\
\hline Go Term & GO:0005876 & Spindle Microtubules & 2 of 47 & 1.35 & $4.1 \times 10-2$ & \\
\hline Go Term & GO:000777 & Condensed Chromosome Kinetochore & 4 of 104 & 1.31 & $2.3 \times 10-3$ & \\
\hline \multirow[t]{2}{*}{ Go Term } & GO:0000775 & Chromosome : Centrometric Region & 5 of 189 & 1.15 & $1.9 \times 10-3$ & \\
\hline & \multicolumn{5}{|c|}{ KEGG Pathways } & \\
\hline Pathway & hsa04350 & TGF-beta Signaling Pathway & 3 of 83 & 1.28 & $1.6 \times 10-2$ & \\
\hline \multirow[t]{2}{*}{ Pathway } & hsa04010 & MAPK Signaling Pathway & 4 of 293 & 0.86 & $3.2 \times 10-2$ & \\
\hline & \multicolumn{6}{|c|}{ Annotated Keywords (UniProt) } \\
\hline Keyword & KW-0498 & Mitosis & 7 of 268 & 1.14 & $7.8 \times 10-5$ & \\
\hline Keyword & KW-0493 & Microtubule & 5 of 275 & 0.98 & $2.1 \times 10-3$ & \\
\hline
\end{tabular}

FDR $=$ False Discovery Rate, Color Code $=$ String Mode Ball Gene Symbol Match

Figure 6. Functional analysis of the 52 transcripts overlaps in DEGs by paclitaxel and GM-4-53 vs. controls. The data represent significant functional changes as identified by several databases: local network cluster (STRING), Kegg pathways, Reactome Pathways expected protein domains and feature (Interpore), where data are reflected by count in network, strength, and false discovery rates. 


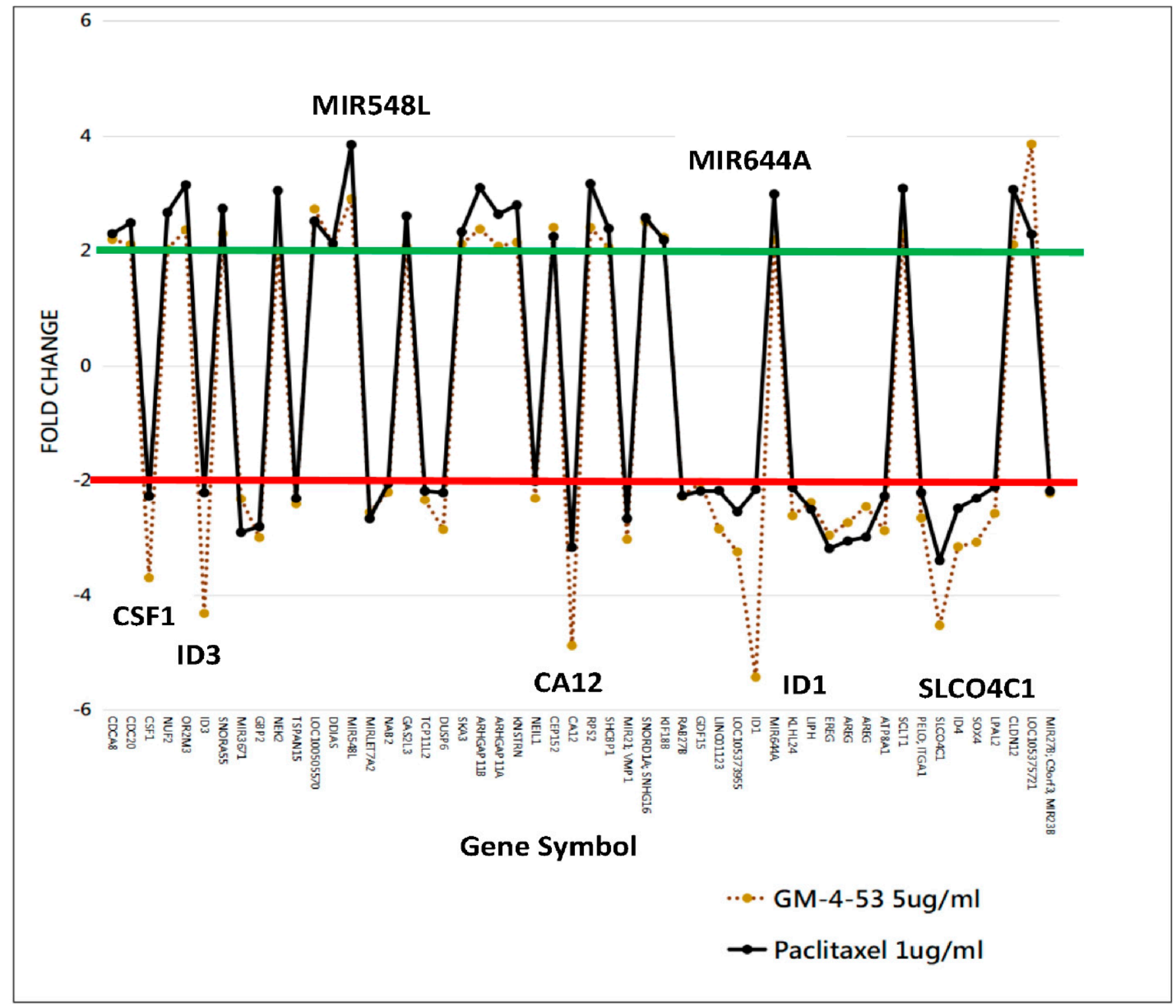

Figure 7. Overlapping DEG profile between GM-4-53 and paclitaxel. The data represent fold change for genes meeting the selection criteria $=$ FC $>2$ or $<-2, p$-value $<0.05$, and FDR $p$-value $<0.05$. 
Table 2. Overlapping DEG profiles between GM-4-53 and paclitaxel. The data represent fold change for genes meeting the selection criteria $=$ FC $>2$ or $<-2, p$-value $<0.05$, and FDR $p$-value $<0.05$.

\begin{tabular}{|c|c|c|c|c|c|c|c|}
\hline \multirow[b]{2}{*}{ Symbol } & \multirow[b]{2}{*}{ Description } & \multicolumn{3}{|c|}{ Paclitaxel } & \multicolumn{3}{|c|}{ GM-4-53 } \\
\hline & & FC & $p$-Value & FDR $p$-Value & FC & $p$-Value & FDR $p$-Value \\
\hline AREG & amphiregulin & -3.06 & $1.0 \times 10^{-4}$ & $2.5 \times 10^{-2}$ & -2.74 & $1.0 \times 10^{-4}$ & $1.2 \times 10^{-2}$ \\
\hline ARHGAP11A & Rho GTPase activating protein $11 \mathrm{~A}$ & 2.64 & $3.3 \times 10^{-6}$ & $1.2 \times 10^{-3}$ & 2.08 & $3.3 \times 10^{-6}$ & $1.1 \times 10^{-3}$ \\
\hline ARHGAP11B & Rho GTPase activating protein 11B & 3.10 & $6.8 \times 10^{-6}$ & $5.3 \times 10^{-3}$ & 2.38 & $3.9 \times 10^{-5}$ & $5.5 \times 10^{-3}$ \\
\hline ATP8A1 & ATPase, (APLT), class I, 8A, m1 & -2.27 & $2.2 \times 10^{-6}$ & $3.3 \times 10^{-3}$ & -2.88 & $4.9 \times 10^{-9}$ & $1.7 \times 10^{-5}$ \\
\hline CA12 & carbonic anhydrase XII & -3.17 & $8.6 \times 10^{-8}$ & $5.0 \times 10^{-4}$ & -4.88 & $3.0 \times 10^{-11}$ & $1.3 \times 10^{-6}$ \\
\hline CDC20 & cell division cycle 20 & 2.49 & $3.0 \times 10^{-4}$ & $4.2 \times 10^{-2}$ & 2.11 & $7.0 \times 10^{-4}$ & $3.5 \times 10^{-2}$ \\
\hline CDCA8 & cell division cycle associated 8 & 2.30 & $6.7 \times 10^{-5}$ & $1.9 \times 10^{-2}$ & 2.20 & $3.2 \times 10^{-5}$ & $4.9 \times 10^{-3}$ \\
\hline CEP152 & centrosomal protein $152 \mathrm{kDa}$ & 2.25 & $2.0 \times 10^{-4}$ & $3.4 \times 10^{-2}$ & 2.41 & $3.6 \times 10^{-5}$ & $5.2 \times 10^{-3}$ \\
\hline CLDN12 & claudin 12 & 3.07 & $1.6 \times 10^{-7}$ & $8.0 \times 10^{-4}$ & 2.11 & $5.0 \times 10^{-6}$ & $1.4 \times 10^{-3}$ \\
\hline CSF1 & colony stimulating factor 1 & -2.27 & $2.1 \times 10^{-6}$ & $3.3 \times 10^{-3}$ & -3.70 & $8.8 \times 10^{-11}$ & $1.3 \times 10^{-6}$ \\
\hline DDIAS & $\begin{array}{l}\text { DNA damage-induced apoptosis } \\
\text { suppressor }\end{array}$ & 2.13 & $1.6 \times 10^{-6}$ & $2.8 \times 10^{-3}$ & 2.11 & $7.1 \times 10^{-7}$ & $4.0 \times 10^{-4}$ \\
\hline DUSP6 & dual specificity phosphatase 6 & -2.21 & $9.2 \times 10^{-8}$ & $5.0 \times 10^{-4}$ & -2.86 & $8.8 \times 10^{-11}$ & $1.3 \times 10^{-6}$ \\
\hline EREG & epiregulin & -3.19 & $8.6 \times 10^{-5}$ & $2.1 \times 10^{-2}$ & -2.96 & $9.4 \times 10^{-6}$ & $2.2 \times 10^{-3}$ \\
\hline GAS2L3 & growth arrest-specific 2 like 3 & 2.61 & $7.9 \times 10^{-6}$ & $5.8 \times 10^{-3}$ & 2.08 & $5.9 \times 10^{-5}$ & $7.3 \times 10^{-3}$ \\
\hline GBP2 & $\begin{array}{l}\text { guanylate binding protein 2, } \\
\text { interferon-inducible }\end{array}$ & -2.81 & $1.7 \times 10^{-5}$ & $8.6 \times 10^{-3}$ & -3.00 & $1.2 \times 10^{-6}$ & $6.0 \times 10^{-4}$ \\
\hline GDF15 & growth differentiation factor 15 & -2.18 & $4.0 \times 10^{-4}$ & $4.2 \times 10^{-2}$ & -2.03 & $6.0 \times 10^{-5}$ & $7.3 \times 10^{-3}$ \\
\hline ID1 & $\begin{array}{l}\text { inhibitor of DNA binding 1, } \\
\text { dom-HLHP }\end{array}$ & -2.15 & $2.0 \times 10^{-4}$ & $3.2 \times 10^{-2}$ & -5.43 & $1.3 \times 10^{-10}$ & $1.3 \times 10^{-6}$ \\
\hline ID3 & $\begin{array}{c}\text { inhibitor of DNA binding 3, } \\
\text { dom-HLHP }\end{array}$ & -2.21 & $8.5 \times 10^{-4}$ & $2.1 \times 10^{-2}$ & -4.32 & $1.4 \times 10^{-10}$ & $1.3 \times 10^{-6}$ \\
\hline ID4 & $\begin{array}{c}\text { inhibitor of DNA binding } 4, \\
\text { dom-HLHP }\end{array}$ & -2.49 & $1.0 \times 10^{-5}$ & $6.2 \times 10^{-3}$ & -3.16 & $1.4 \times 10^{-7}$ & $1.0 \times 10^{-4}$ \\
\hline KIF18B & kinesin family member $18 \mathrm{~B}$ & 2.19 & $2.8 \times 10^{-5}$ & $1.2 \times 10^{-2}$ & 2.24 & $5.2 \times 10^{-6}$ & $1.4 \times 10^{-3}$ \\
\hline KLHL24 & kelch-like family member 24 & -2.12 & $1.0 \times 10^{-4}$ & $2.7 \times 10^{-2}$ & -2.62 & $7.6 \times 10^{-7}$ & $4.0 \times 10^{-4}$ \\
\hline KNSTRN & kinetochore-loc. astrin/SPAG5bp & 2.80 & $3.6 \times 10^{-7}$ & $1.2 \times 10^{-3}$ & 2.15 & $4.5 \times 10^{-6}$ & $1.3 \times 10^{-3}$ \\
\hline LIPH & lipase, member $\mathrm{H}$ & -2.51 & $2.5 \times 10^{-6}$ & $3.4 \times 10^{-3}$ & -2.38 & $8.8 \times 10^{-7}$ & $5.0 \times 10^{-4}$ \\
\hline LPAL2 & lipoprotein, Lp(a)-like 2, pg & -2.11 & $4.0 \times 10^{-4}$ & $4.6 \times 10^{-2}$ & -2.58 & $1.3 \times 10^{-5}$ & $2.6 \times 10^{-3}$ \\
\hline NAB2 & $\begin{array}{l}\text { NGFI-A binding protein } 2 \text { (EGR1 } \\
\text { binding protein 2) }\end{array}$ & -2.05 & $3.0 \times 10^{-4}$ & $3.9 \times 10^{-2}$ & -2.20 & $8.6 \times 10^{-6}$ & $2.0 \times 10^{-3}$ \\
\hline NEIL1 & nei-like DNA glycosylase 1 & -2.01 & $4.7 \times 10^{-5}$ & $1.5 \times 10^{-2}$ & -2.31 & $6.5 \times 10^{-7}$ & $4.0 \times 10^{-4}$ \\
\hline NEK2 & NIMA-related kinase 2 & 3.05 & $4.7 \times 10^{-5}$ & $1.5 \times 10^{-2}$ & 2.00 & $7.0 \times 10^{-4}$ & $3.5 \times 10^{-2}$ \\
\hline NUF2 & NUF2, NDC80 kinetochore com c & 2.67 & $5.9 \times 10^{-5}$ & $1.7 \times 10^{-2}$ & 2.03 & $5.0 \times 10^{-4}$ & $2.9 \times 10^{-2}$ \\
\hline PELO; ITGA1 & pelota hom (Dros); integrin alpha 1 & -2.21 & $2.0 \times 10^{-4}$ & $3.5 \times 10^{-2}$ & -2.66 & $2.3 \times 10^{-6}$ & $8.0 \times 10^{-4}$ \\
\hline RAB27B & $\begin{array}{l}\text { RAB27B, member RAS oncogene } \\
\text { family }\end{array}$ & -2.26 & $4.1 \times 10^{-5}$ & $1.5 \times 10^{-2}$ & -2.27 & $1.1 \times 10^{-6}$ & $6.0 \times 10^{-4}$ \\
\hline RPS2 & ribosomal protein $\mathrm{S} 2$ & 3.17 & $5.4 \times 10^{-7}$ & $1.7 \times 10^{-3}$ & 2.41 & $3.3 \times 10^{-6}$ & $1.1 \times 10^{-3}$ \\
\hline SCLT1 & sodium channel/clathrin linker 1 & 3.09 & $2.7 \times 10^{-7}$ & $1.1 \times 10^{-3}$ & 2.30 & $3.5 \times 10^{-6}$ & $1.1 \times 10^{-3}$ \\
\hline SHCBP1 & SHC SH2-domain binding protein 1 & 2.39 & $5.1 \times 10^{-5}$ & $1.6 \times 10^{-2}$ & 2.06 & $6.4 \times 10^{-5}$ & $7.7 \times 10^{-3}$ \\
\hline SKA3 & Spindle \& Kinetochore complex s3 & 2.33 & $1.0 \times 10^{-4}$ & $2.7 \times 10^{-2}$ & 2.12 & $2.0 \times 10^{-4}$ & $1.3 \times 10^{-2}$ \\
\hline SLCO4C1 & $\mathrm{SC}$ organic anion transporter $\mathrm{fm} 4 \mathrm{C} 1$ & -3.40 & $3.7 \times 10^{-6}$ & $4.0 \times 10^{-3}$ & -4.53 & $1.2 \times 10^{-8}$ & $2.8 \times 10^{-5}$ \\
\hline SOX4 & SRY box 4 & -2.31 & $5.4 \times 10^{-6}$ & $4.9 \times 10^{-3}$ & -3.08 & $2.0 \times 10^{-9}$ & $9.6 \times 10^{-6}$ \\
\hline TSPAN15 & tetraspanin 15 & -2.31 & $1.1 \times 10^{-6}$ & $2.3 \times 10^{-3}$ & -2.41 & $9.7 \times 10^{-8}$ & $1.0 \times 10^{-4}$ \\
\hline
\end{tabular}

The comparable efficacy of the two drugs in 3D tumor models was also established (Figure 8). Although a dose-response was carried out, a consistent morphological pattern of grossly distorted cytostatic cells was observed throughout all effective doses tested, as shown in Figure 2. The data in Figure 8 show a very distinct and unusual pattern between the two drugs, where paclitaxel appears to halt the growth of the spheroid and central core, whereas GM-4-53 halts the growth and appears to penetrate the tumor core, leading to mass dispersion of viable cytostatic cells. The ramifications of these findings need further investigation. 


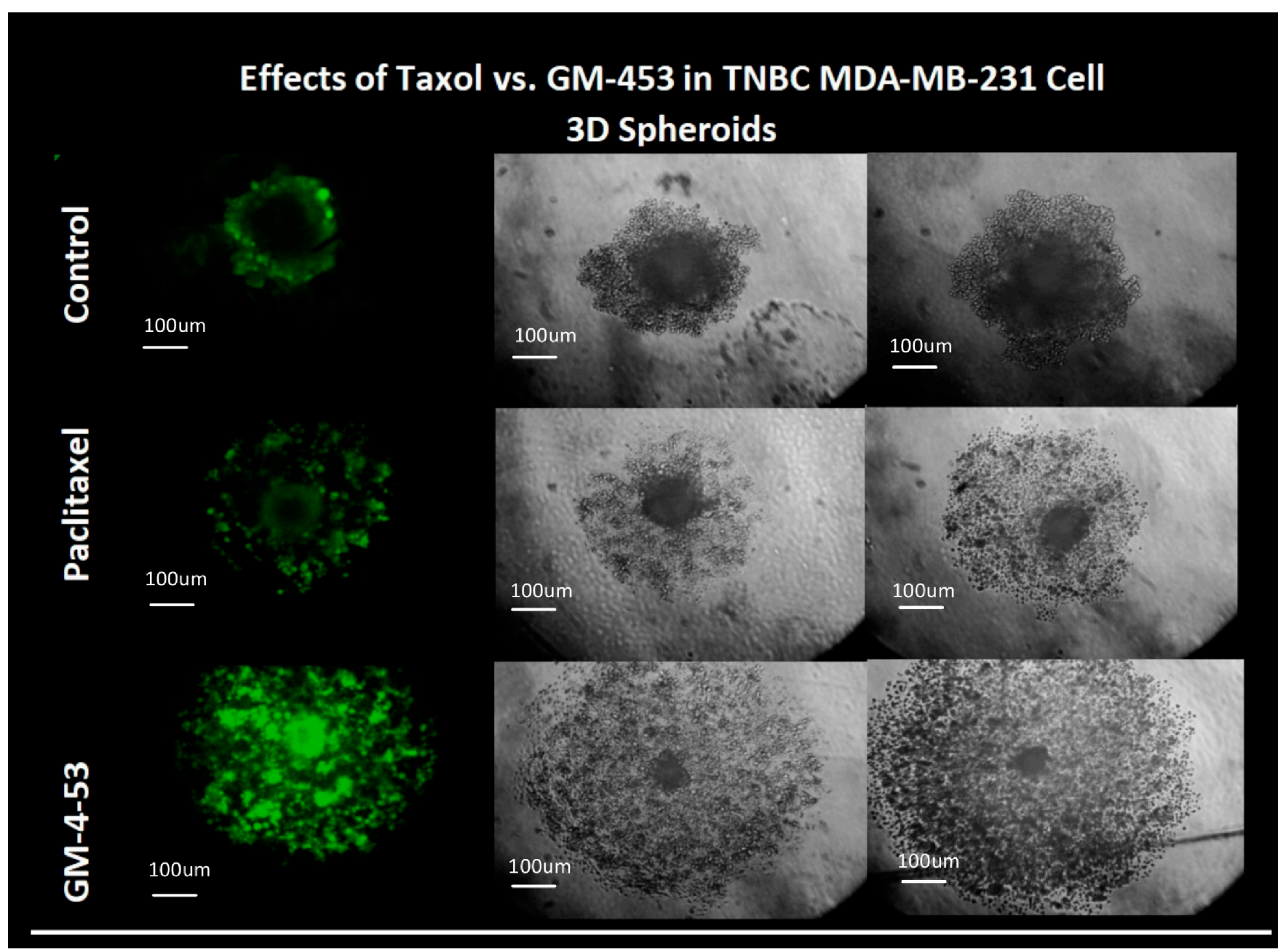

Figure 8. Effect of GM-4-53 $(5 \mu \mathrm{g} / \mathrm{mL})$ and paclitaxel $(1 \mu \mathrm{g} / \mathrm{mL})$ on 3D tumors. The left panel represents cell viability (fluorescein diacetate), and the right 2 panels show basic cell morphology $(n=2)$.

\section{Discussion}

The data in this work provide basic information on the transcriptome profile in response to the two cytostatic drugs (paclitaxel and GM-4-53) in a TNBC model. There is no doubt that GM-4-53 has many anticancer effects in common with paclitaxel, as both are cytostatic drugs, which fully block the cell cycle at non-cytotoxic concentrations, and evoke massive changes in the cytoskeletal architecture, disrupting microtubule dynamics and inducing cell-cycle arrest. Microtubule dynamics disrupters are mainline cancer drugs, as they can block the normal equilibrium, which allows cell structures to expand, retract, change shape, divide, and move. Cytostatic compounds such as paclitaxel are a front-line treatment in many cancers because they impair the dynamics of cytoskeletal fluidity in cancer cells, paralyzing microtubules (stabilized) by either blocking tubulin depolymerization or polymerization (destabilized), meaning that cell division is no longer possible [42,43]. This can occur via two basic classes of drugs (1) (e.g., taxanes, epothilones, cyclosstreptin, steroids, lactones, and natural compounds), referred to as microtubules stabilizing agents (MSA)s, which block tubulin depolymerization, or (2) drugs that inhibit polymerization of tubulin (destabilizing agents) (MDAs) such as colchicine, vinblastine and combretastatin-A4 [44]. MDAs and MSAs block cell-cycle progression holding the filaments static, thereby preventing chromosome attachment/segregation and spindle formation required for mitotic cell division $[45,46]$. The limitations to using these drugs to 
treat cancer, as is the case for paclitaxel, include inherent side effects, chemoresistance, and poor aqueous solubility, with limited access to the blood-brain barrier [47,48].

Drug therapeutic failures are ultimately responsible for mortality rates. As a result, there is a continuous demand for safe and efficient alternatives to TNBC cytostatic drugs, which may work through a different mechanism, enabling improved antitumor response and patient outcome. After our lab revealed GM-4-53 to be a potent cytostatic agent, the first obvious target evaluated was its effect on the tubulin polymerization/depolymerization processes; where the data failed to show any effect and showed only mild effects on the process of tubulin nucleation, suggesting there must be additional mechanisms in play [37].

Interestingly, while the effects of paclitaxel are not believed to involve a mechanism of action occurring at the gene level, the findings in this work were not expected, showing that many elements of the cell cycle are altered at the transcriptome level. It was also surprising to find significant overlap in the transcriptome in response to paclitaxel and GM-4-53, particularly in downregulated transcripts require for cell cycle and mitosis. Secondly, the data show DEG shifts that are unique to paclitaxel, which is reportedly observed to be associated with taxol chemoresistance, such as upregulated transcription of kinesin superfamily members, spindle assembly processes (e.g., MAD2, KIF11 (also known as kinesin-5 and Eg5), centrosomal proteins, centromere proteins, cell-division-cycle-associated genes, cyclins, centrioles, and aurora A, some of which also amplify chromosomal and spindle processes in paclitaxel refractory cancers [49-52] (see Supplementary Table S1). Information from whole-transcriptomic analysis on the effects of paclitaxel in this study may also provide information on changes that could align with drug resistance. While paclitaxel has been rigorously studied for decades, there is no known information on GM-4-53 or how it mediates its effect on cell division. For this reason, we searched for DEG overlaps in common to both drugs. Both drugs caused a pronounced downregulation of "inhibitor of DNA Binding/Inhibitor of differentiation" (ID) transcripts for ID1, ID3, and ID4, with GM-4-53 having more significant effects than paclitaxel. IDs are implicated in the control of cell division and mitosis not only during embryonic development but also in numerous cancers, including TNBC, being linked to larger tumor size, advanced histological grade, metastasis, vascular invasion, stem cell phenotype, lymph node invasion, and poor clinical outcomes [53,54]. The ID genes may control cell division by the indirect regulation of processes involving CDKN1A (p21) and CDKN1B (p27) [55]. In TNBC and other cancers, the ID oncogenic transcripts foster diverse cancer-related events, including EMT, signaling (e.g., EGFR/TGF-beta [56-61], K-Ras, WNT, STAT3, PI3K/Akt, OCT-4/ID1/NF-kappaB), where ID genes are a target of many anticancer drugs, including vinblastine [62,63]. Drugs such as GM-4-53 that can downregulate IDs are believed to offer therapeutic roles in the attenuation of TNBC progression and other cancers [64-66], with a capacity to offset chemoresistance associated with various drugs [67-71]. Regarding the impact of downregulated ID transcripts by both paclitaxel and GM-4-53, these are known to play a direct role in impeding cell division. Several studies seem to suggest that ID1 exerts control over cell cycle and self-renewal capacity of TNBC in vitro and in vivo [57], with its absence (silencing) leading to G0/G1 cell cycle arrest [56].

The data in this work also show that both paclitaxel and GM-4-53 co-downregulate both amphiregulin (AREG) and epiregulin (EREG) mRNAs, which are required for breast luminal development (by EGF binding/activating EGFR (ERBB)), and, when overexpressed, are linked to aggressive breast cancers of diverse type (ER + erb2, HER2 and TNBC) [72-76]. AREG/EREGs are also involved with enhanced tumor cell proliferation but equally capable of propelling the fibrotic processes required for the development of cancer-associated fibroblasts (CAFS), which establish a conducive tumor microenvironment (TME) for rapid tumor proliferation [77-80]. In brief, AREG/EREG ectodomain ligands are initially shed by the tumor necrosis factor-alpha-converting enzyme (TACE), with subsequent integration into exosomes. They are fully competent as ligands, which then bind/activate tumor EGFR (ErbB1-4) receptors to trigger oncogenic signaling: (phosphatidylinositol 3-kinase/Akt, Ras/Raf/MEK/ERK1/2, and phospholipase C), which also leads to sustained release of 
cytokines that cause leukocyte infiltration to the tumor microenvironment (TME) [81,82]. Additionally, GM-4-53 reduced the expression of Intercellular adhesion molecule 1 (ICAM1), which is a driver of cell migration via the docking and trafficking of leukocytes toward cancer and stromal cells $[83,84]$. In addition, its intra-cellular product (pro-AREG) enters the nucleus, where it activates potent oncogenes [85-88]. The well-known tumor-promoting role of EGFT ligand/receptors is the premise behind existing chemotherapies [89], such as (cetuximab pertuzumab, trastuzumab), which bind ligands or interacts with the receptor (gefitinib, erlotinib, and lapatinib) [90]. Similar to EREG, drugs that interfere with AREG, particularly in chemoresistant breast cancers, effectively acquiesce tumor growth, tumorassociated macrophage (TAM) infiltration [91] and block the activation of diverse EGF receptors (ErbB1, 3 and 4+ ErbB2 HER2/Neu) [92-95].

While these are just a few promising aspects of GM-4-53, future work will be required to elucidate both the therapeutic and limiting factors of this drug. The data from this work clearly define the following: this drug is a cytostatic, non-cytotoxic agent with a similar effect on TNBC to the mainline drug, paclitaxel. The lack of cytotoxicity by paclitaxel has been observed in ex vivo explants of human breast tumors, which penetrate a tumor and disrupt mitosis without directly invoking cytotoxicity [96]. There is a clear distinction between cytotoxic drugs vs. cytostatic drugs, demarcated by the extremely large difference in drug dose concentrations between lower-dose effective blocks on cell proliferation $\left(\mathrm{IG}_{50}\right)$ vs. cell viability ratios $\left(\mathrm{IC}_{50}\right)$, where dead cells do not divide. While the data in this work also show that both drugs affect established 3D spheroid tumors, GM-453 appears to have significant effects on the clustering of cells or penetration of the tumor spheroid, which could theoretically either prevent tumor formation and/or alter the metastatic proclivity of circulating tumor cells [97].

\section{Conclusions}

In this work, we show that GM-4-53 displays several areas of potential targeted chemotherapy efficacy. Given the efficient solubility of GM-4-53, its low molecular weight (MW; 296), ability to penetrate a small solid tumor mass and effectively block the cell cycle, this drug may have future therapeutic value in treating TNBC or other cancers. Further research will be needed, including in vitro and in vivo preclinical work to establish limitations, safety guidelines, pharmacokinetics, and potential applications of this drug.

\section{Materials and Methods}

Hanks balanced salt solution (HBSS), (4-(2-hydroxyethyl)-1-piperazine-ethanesulfonic acid) (HEPES), ethanol, 96-well plates, flasks, paclitaxel, general reagents, and supplies were purchased from Sigma-Aldrich Co. (St. Louis, MO, USA) and VWR International (Radnor, PA, USA).

\subsection{Chemistry}

The synthesis and characterization of tetrahydroisoquinoline GM-4-53 have been described previously [37]. O-mesitylene sulfonyl hydroxylamine (MSH) was used to prepare the $\mathrm{N}$-amino salt as an aminating agent, as previously reported [36]. MSH (22.74 mmol) was added, in dry methylene chloride $(10 \mathrm{~mL})$, an ice-cool solution of 7-hydroxyisoquinoline (20.67 mmol) in anhydrous methylene chloride and anhydrous methanol (1:1) $(60 \mathrm{~mL})$, over $5 \mathrm{~min}$ with stirring. The reaction was stirred at $0{ }^{\circ} \mathrm{C}$ for $6 \mathrm{~h}$, as previously reported in the procedure. 4-ethyl benzoyl chloride $(8.32 \mathrm{mmol})$ was added to an ice-cold solution of $\mathrm{N}$-amino salt $(4.16 \mathrm{mmol})$ in anhydrous tetrahydrofuran $(40 \mathrm{~mL})$ containing trimethylamine $(2.0 \mathrm{~mL})$. The mixture was allowed to proceed for $12 \mathrm{~h}$ at $70{ }^{\circ} \mathrm{C}$ to obtain $\mathrm{N}$-ylide as a stable crystalline solid. Sodium borohydride $(50.0 \mathrm{mmol})$ reduction of ylide in absolute ethanol $(50 \mathrm{~mL})$ furnished the 4-Ethyl- $N$-(7-hydroxy-3,4-dihydroisoquinolin-2(1H)-yl) benzamide (GM-4-53), with fair to good yield (65\% yield). 


\subsection{Cell Culture}

In this study, TNBC MDA-MB-231 cells (ATCC ${ }^{\circledR}$ HTB-26 ${ }^{\mathrm{TM}}$ ) were obtained from American Type Culture Collection (Manassas, VA, USA). MDA-MB-231 cells were initially brought up in ATCC-formulated Leibowitz's L-15 medium, supplemented with $10 \%$ fetal bovine serum (FBS) and penicillin/streptomycin $(100 \mathrm{U} / 0.1 \mathrm{mg} / \mathrm{mL})$. After confluence, the cells were sub-cultured and grown in Dulbecco's modified Eagle's medium (DMEM), containing phenol red, 7.5\% FBS, $4 \mathrm{mM}$ L-glutamine, $20 \mu \mathrm{M}$ sodium pyruvate, and penicillin/streptomycin $(100 \mathrm{U} / 0.1 \mathrm{mg} / \mathrm{mL})$. Cells were maintained at $37^{\circ} \mathrm{C}$ in $5 \% \mathrm{CO}_{2} /$ atmosphere and, every $2-5$ days, the medium was replaced, and cells were sub-cultured.

The anti-proliferative activity of GM-4-53 on two additional cell lines was evaluated at the Southern Research Institute (SRI, Birmingham, Alabama, USA). There, the human MCF7 breast cancer cell line was purchased from the NCI. The human Ishikawa endometrial cancer cell line was purchased from Sigma Aldrich. Both cell lines were cultured in phenol red-free RPMI-1640 (Hyclone) $(500 \mathrm{~mL})$, supplemented with L-glutamine-dipeptide (Hyclone) (5 mL), and 10\% fetal bovine serum (Atlanta Biologicals) $(50 \mathrm{~mL})$.

\subsection{Proliferation and Cell Viability Studies}

For MDA-MB-231 cells, both paclitaxel and GM-4-53 were dissolved in DMSO and stored at $-20^{\circ} \mathrm{C}$. A stock solution for both compounds was prepped in HBSS. In brief, 96-well plates were seeded with cells $\left(0.04 \times 10^{5}\right.$ /well) to a volume of $200 \mu \mathrm{L}$, to which drugs were added, and cell proliferation (as cell count) was evaluated at a 6-day endpoint, using Alamar blue. For Alamar blue testing, a working solution of resazurin prepared in sterile phosphate-buffered saline (PBS)-phenol red $(0.5 \mathrm{mg} / \mathrm{mL})$ was added $(15 \% \mathrm{v} / \mathrm{v})$ to each sample in a 96-well plate. Samples were returned to the incubator for 4-6 h, and the reduction in the dye (to resorufin, a fluorescent compound) caused by viable cells was quantitatively analyzed using a Synergy HTX multi-mode reader (Bio-Tek, Winooski, VT, USA), with excitation/emission wavelength settings at $550 \mathrm{~nm} / 580 \mathrm{~nm}$. Cell count was evaluated as \% control, and the inhibitory growth $\left(\mathrm{IG}_{50}\right)$ value was calculated by regression analysis. Cytotoxicity studies were carried out at equal dose concentrations as proliferation studies at a higher plating density $\left(0.5 \times 10^{5} /\right.$ well $)$, over $24-36 \mathrm{~h}$. The cytostatic effects of MCF-7 and Ishikawa cell lines were determined using the CellTiter-Glo (CTG) luminescent cell viability assay, which is based on the direct determination of intracellular ATP level (determining the number of viable cells in culture based on the quantification of ATP present), which signals the presence of metabolically active cells. Luminescence results were read on TriLux Luminometer. Optimal concentrations for microarray were established by a lack of cell toxicity, at a concentration showing a complete blockage of cell proliferation; paclitaxel $(1 \mu \mathrm{g} / \mathrm{mL})$ and GM-4-53 $(5 \mu \mathrm{g} / \mathrm{mL})$. For microarray studies, cells were plated and treated in $75 \mathrm{~cm} 3$ flasks for $36 \mathrm{~h}$.

\subsection{D Tumor Studies}

MDA-MB-231 cells were plated in low-adhesion, round-bottom, sterile, 96-well plates at a cell density of $\left(0.2 \times 10^{5} /\right.$ well $)$, in $200 \mathrm{uL}$ of cell culture media centrifuged at $1800 \times g$ for 3 min prior to incubation at $37^{\circ} \mathrm{C}$ in $5 \% \mathrm{CO}_{2} /$ atmosphere. For the first 3 days, cells were taken out and re-centrifuged at $1800 \times g \times 3 \mathrm{~min}$. 3D spheroids were left to grow for 10 days. On day 14, experimental drugs were added, and images were captured on day 24.

\subsection{Imaging}

2D cell cultures were imaged to ascertain changes in morphological structure at the 6-day endpoint in MDA-MB-231 cells in the presence or absence of treatments. In brief, cells were fixed in $4 \%$ paraformaldehyde and incubated at $37^{\circ} \mathrm{C}$ in $5 \% \mathrm{CO}_{2} /$ atmosphere for $15 \mathrm{~min}$. After delicate removal of paraformaldehyde, sterile ultra-pure biological grade water containing $0.2 \%$ Triton X-100 was gently added to each well $(100 \mathrm{uL})$ and returned to the incubator for $45 \mathrm{~min}$. After gentle removal, a PBS solution containing propidium 
iodide $(1 \mu \mathrm{g} / \mathrm{mL})$ and Phalloidin-iFluor 488 Reagent (ab176753) was added to each well, according to the manufacturer's instructions Abcam (Cambridge, MA, USA), and images were captured on an inverted fluorescent microscope using the $10 \times$ and $25 \times$ fluo-objectives. 3D tumors were stained with fluorescein diacetate (live-cell dye) and countered imaged for morphology.

\subsection{Microarray WT 2.1 Human Datasets}

After the experimental 36-h time point, the cells were scraped, washed three times in ice-cold HBSS, and spun down. The supernatant was removed, and the remaining pellet was rapidly frozen and stored at $-80{ }^{\circ} \mathrm{C}$. Total RNA was isolated and purified using the Trizol/chloroform method. The RNA quality was assessed, and concentrations were equalized to $82 \mathrm{ng} / \mu \mathrm{L}$ in nuclease-free water. According to the GeneChipTM WT PLUS Reagent Manual for Whole Transcript (WT) expression arrays, whole-transcriptome analysis was conducted. In brief, RNA was reverse-transcribed to first-strand/secondstrand cDNA, followed by cRNA amplification and purification. After the 2nd cycle of ss-cDNA Synthesis and hydrolysis of RNA, ss-cDNA was assessed for yield, fragmented, labeled, and hybridized onto the arrays before being subjected to fluidics and imaging using the Gene Atlas Affymetrix, ThermoFisher Scientific (Waltham, MA, USA). The array data, quality control, and initial processing from CEL to CHP files were conducted using an expression console before data evaluation using the Affymetrix transcriptome analysis console (Wiki/Kegg pathways) and protein-protein interaction (PPI) String Database (String Consortium 2020) https:/ / string-db.org, accessed on 25 March 2021 [98,99], n= 3.

\subsection{Data Analysis}

Statistical analysis was performed using Graph Pad Prism (San Diego, CA, USA). The significance of the difference between groups was assessed using a one-way ANOVA, followed by the Tukey post hoc means comparison test or Student's $t$-test. $\mathrm{IG}_{50}$ s were determined by regression analysis using origin software Origin Lab (Northampton, MA, USA).

Supplementary Materials: The following are available online at https: / www.mdpi.com/article/ $10.3390 /$ ijms22147694/s1.

Author Contributions: M.G. synthesized the chemical drugs. E.A.M. carried out the basic culture studies and microarray work. K.F.A.S. and K.K.R. oversaw this project from start to finish by scientific consultation, guidance, manuscript preparation, and review. All authors have read and agreed to the published version of the manuscript.

Funding: This research was funded by the National Institute of Minority Health and Health Disparities of the National Institutes of Health, Grant Number U54 MD007582.

Institutional Review Board Statement: Not Applicable.

Informed Consent Statement: Not Applicable.

Data Availability Statement: The dataset has been deposited to NIH Gene Expression Omnibus located at https:/ / www.ncbi.nlm.nih.gov/geo/query/acc.cgi?acc=GSE163046. Published on 12 December 2020.

Conflicts of Interest: The authors declare no conflict of interest.

\section{References}

1. Sturtz, L.A.; Melley, J.; Mamula, K.; Shriver, C.D.; Ellsworth, R.E. Outcome disparities in African American women with triple-negative breast cancer: A comparison of epidemiological and molecular factors between African American and Caucasian women with triple-negative breast cancer. BMC Cancer 2014, 14, 62. [CrossRef] [PubMed]

2. Vidal, G.; Bursac, Z.; Miranda-Carboni, G.; White-Means, S.; Starlard-Davenport, A. Racial disparities in survival outcomes by breast tumor subtype among African American women in Memphis, Tennessee. Cancer Med. 2017, 6, 1776-1786. [CrossRef]

3. Sakhuja, S.; Deveaux, A.; Wilson, L.E.; Vin-Raviv, N.; Zhang, D.; Braithwaite, D.; Altekruse, S.; Akinyemiju, T. Patterns of de-novo metastasis and breast cancer-specific mortality by race and molecular subtype in the SEER population-based dataset. Breast Cancer Res. Treat. 2020, 186, 509-518. [CrossRef] [PubMed] 
4. Verma, S.; Provencher, L.; Dent, R. Emerging trends in the treatment of triple-negative breast cancer in Canada: A survey. Curr. Oncol. 2011, 18, 180-190. [CrossRef]

5. Lorusso, V.; Latorre, A.; Giotta, F. Chemotherapy Options beyond the First Line in HER-Negative Metastatic Breast Cancer. J. Oncol. 2020, 2020, 9645294. [CrossRef]

6. Ingvarsson, S. Molecular genetics of breast cancer progression. Semin. Cancer Biol. 1999, 9, 277-288. [CrossRef] [PubMed]

7. Cline, M.J.; Battifora, H.; Yokota, J. Proto-oncogene abnormalities in human breast cancer: Correlations with anatomic features and clinical course of the disease. J. Clin. Oncol. 1987, 5, 999-1006. [CrossRef]

8. Ping, Z.; Xia, Y.; Shen, T.; Parekh, V.; Siegal, G.P.; Eltoum, I.E.; He, J.; Chen, D.; Deng, M.; Xi, R.; et al. A microscopic landscape of the invasive breast cancer genome. Sci. Rep. 2016, 6, 27545. [CrossRef]

9. Yang, D.C.; Elliott, R.L.; Head, J.F. Gene targets of antisense therapies in breast cancer. Expert Opin. Ther. Targets 2002, 6, 375-385. [CrossRef]

10. Wang, S.; Li, X.; Zhang, W.; Gao, Y.; Zhang, K.; Hao, Q.; Li, W.; Wang, Z.; Li, M.; Zhang, W.; et al. Genome-Wide Investigation of Genes Regulated by ERalpha in Breast Cancer Cells. Molecules 2018, 23, 2543. [CrossRef]

11. Shabnaz, S.; Ahmed, M.U.; Islam, M.S.; Islam, M.R.; Al-Mamun, M.M.; Islam, M.S.; Hasnat, A. Breast cancer risk in relation to TP53 codon 72 and CDH1 gene polymorphisms in the Bangladeshi women. Tumour Biol. 2016, 37, 7229-7237. [CrossRef] [PubMed]

12. Bareche, Y.; Venet, D.; Ignatiadis, M.; Aftimos, P.; Piccart, M.; Rothe, F.; Sotiriou, C. Unravelling triple-negative breast cancer molecular heterogeneity using an integrative multiomic analysis. Ann. Oncol. 2018, 29, 895-902. [CrossRef]

13. Muendlein, A.; Rohde, B.H.; Gasser, K.; Haid, A.; Rauch, S.; Kinz, E.; Drexel, H.; Hofmann, W.; Schindler, V.; Kapoor, R.; et al. Evaluation of BRCA1/2 mutational status among German and Austrian women with triple-negative breast cancer. J. Cancer Res. Clin. Oncol. 2015, 141, 2005-2012. [CrossRef] [PubMed]

14. Palomba, G.; Budroni, M.; Olmeo, N.; Atzori, F.; Ionta, M.T.; Pisano, M.; Tanda, F.; Cossu, A.; Palmieri, G. Triple-negative breast cancer frequency and type of BRCA mutation: Clues from Sardinia. Oncol. Lett. 2014, 7, 948-952. [CrossRef]

15. Zhou, Z.R.; Wang, X.Y.; Yu, X.L.; Mei, X.; Chen, X.X.; Hu, Q.C.; Yang, Z.Z.; Guo, X.M. Building radiation-resistant model in triple-negative breast cancer to screening radioresistance-related molecular markers. Ann. Transl. Med. 2020, 8, 108. [CrossRef]

16. Li, M.; Li, H.; Liu, F.; Bi, R.; Tu, X.; Chen, L.; Ye, S.; Cheng, X. Characterization of ovarian clear cell carcinoma using target drug-based molecular biomarkers: Implications for personalized cancer therapy. J. Ovarian Res. 2017, 10, 9. [CrossRef]

17. Reddy, T.P.; Rosato, R.R.; Li, X.; Moulder, S.; Piwnica-Worms, H.; Chang, J.C. A comprehensive overview of metaplastic breast cancer: Clinical features and molecular aberrations. Breast Cancer Res. 2020, 22, 121. [CrossRef]

18. Chen, J.; Liu, C.; Cen, J.; Liang, T.; Xue, J.; Zeng, H.; Zhang, Z.; Xu, G.; Yu, C.; Lu, Z.; et al. KEGG-expressed genes and pathways in triple-negative breast cancer: Protocol for a systematic review and data mining. Medicine 2020, 99, e19986. [CrossRef]

19. Shome, R.; Ghosh, S.S. Tweaking EMT, and MDR dynamics to constrain triple-negative breast cancer invasiveness by EGFR and Wnt/beta-catenin signaling regulation. Cell Oncol. 2021, 44, 405-422. [CrossRef]

20. Ring, A.; Kaur, P.; Lang, J.E. EP300 knockdown reduces cancer stem cell phenotype, tumor growth and metastasis in triple-negative breast cancer. BMC Cancer 2020, 20, 1076. [CrossRef] [PubMed]

21. Jurj, A.; Pop, L.A.; Zanoaga, O.; Ciocan-Cartita, C.A.; Cojocneanu, R.; Moldovan, C.; Raduly, L.; Pop-Bica, C.; Trif, M.; Irimie, A.; et al. New Insights in Gene Expression Alteration as Effect of Paclitaxel Drug Resistance in Triple-Negative Breast Cancer Cells. Cell Physiol. Biochem. 2020, 54, 648-664. [PubMed]

22. Zhu, C.; Ge, C.; He, J.; Zhang, X.; Feng, G.; Fan, S. Identification of Key Genes and Pathways Associated with Irradiation in Breast Cancer Tissue and Breast Cancer Cell Lines. Dose Response 2020, 18. [CrossRef] [PubMed]

23. Marczyk, M.; Patwardhan, G.A.; Zhao, J.; Qu, R.; Li, X.; Wali, V.B.; Gupta, A.K.; Pillai, M.M.; Kluger, Y.; Yan, Q.; et al. Multi-Omics Investigation of Innate Navitoclax Resistance in Triple-Negative Breast Cancer Cells. Cancers 2020, 12, 2551. [CrossRef]

24. Li, W.; You, Y.; Zhang, X.; Song, Y.; Xiang, H.; Peng, X.; Qin, J.; Tan, G. Amplification of chromosome 8q21-qter associated with the acquired paclitaxel resistance of nasopharyngeal carcinoma cells. Int. J. Clin. Exp. Pathol. 2015, 8, 12346-12356. [PubMed]

25. Loftus, P.G.; Watson, L.; Deedigan, L.M.; Camarillo-Retamosa, E.; Dwyer, R.M.; O’Flynn, L.; Alagesan, S.; Griffin, M.; O’Brien, T.; Kerin, M.J.; et al. Targeting stromal cell Syndecan-2 reduces breast tumour growth, metastasis and limits immune evasion. Int. J. Cancer 2021, 148, 1245-1259. [CrossRef]

26. Lian, B.; Pei, Y.C.; Jiang, Y.Z.; Xue, M.Z.; Li, D.Q.; Li, X.G.; Zheng, Y.Z.; Liu, X.Y.; Qiao, F.; Sun, W.L.; et al. Truncated HDAC9 identified by the integrated genome-wide screen as the key modulator for paclitaxel resistance in triple-negative breast cancer. Theranostics 2020, 10, 11092-11109. [CrossRef] [PubMed]

27. Ge, W.; Jiang, M.; Zhang, F.; Ma, Y.; Wang, H.; Xu, Y. ZGRF1 Is Associated with Poor Prognosis in Triple-Negative Breast Cancer and Promotes Cancer Stemness Based on Bioinformatics. Oncol. Targets Ther. 2020, 13, 2843-2854. [CrossRef]

28. Zhang, J.; Zhao, J.; Zhang, W.; Liu, G.; Yin, D.; Li, J.; Zhang, S.; Li, H. Establishment of paclitaxel-resistant cell line and the underlying mechanism on drug resistance. Int. J. Gynecol. Cancer 2012, 22, 1450-1456. [CrossRef]

29. Peng, X.; Tan, G. Differential expression of taxol resistance and taxol resistance reversal related genes in nasopharyngeal carcinoma by cDNA microarray. Zhong Nan Da Xue Xue Bao Yi Xue Ban 2012, 37, 48-52.

30. Lai, D.; Ho, K.C.; Hao, Y.; Yang, X. Taxol resistance in breast cancer cells is mediated by the hippo pathway component TAZ and its downstream transcriptional targets Cyr61 and CTGF. Cancer Res. 2011, 71, 2728-2738. [CrossRef] 
31. Li, W.; Tan, G.L.; Ma, Y.H.; Peng, X.W.; He, G.X. Role of folate receptor 1 in paclitaxel-resistance of nasopharyngeal carcinoma cells]. Zhonghua Er Bi Yan Hou Tou Jing Wai Ke Za Zhi 2010, 45, 1035-1040.

32. Karam, J.A.; Huang, S.; Fan, J.; Stanfield, J.; Schultz, R.A.; Pong, R.C.; Sun, X.; Mason, R.P.; Xie, X.J.; Niu, G.; et al. Upregulation of TRAG3 gene in urothelial carcinoma of the bladder. Int. J. Cancer 2011, 128, 2823-2832. [CrossRef] [PubMed]

33. Moelans, C.B.; Verschuur-Maes, A.H.; van Diest, P.J. Frequent promoter hypermethylation of BRCA2, CDH13, MSH6, PAX5, PAX6 and WT1 in ductal carcinoma in situ and invasive breast cancer. J. Pathol. 2011, 225, 222-231. [CrossRef] [PubMed]

34. Zhang, X.; Li, W.; Li, H.; Ma, Y.; He, G.; Tan, G. Genomic methylation profiling combined with gene expression microarray reveals the aberrant methylation mechanism involved in nasopharyngeal carcinoma taxol resistance. Anticancer Drugs 2012, 23, 856-864. [CrossRef]

35. Peng, X.; Cao, P.; He, D.; Han, S.; Zhou, J.; Tan, G.; Li, W.; Yu, F.; Yu, J.; Li, Z.; et al. MiR-634 sensitizes nasopharyngeal carcinoma cells to paclitaxel and inhibits cell growth both in vitro and in vivo. Int. J. Clin. Exp. Pathol. 2014, 7, 6784-6791.

36. Schettini, F.; Giuliano, M.; De Placido, S.; Arpino, G. Nab-paclitaxel for the treatment of triple-negative breast cancer: Rationale, clinical data, and future perspectives. Cancer Treat. Rev. 2016, 50, 129-141. [CrossRef]

37. Gangapuram, M.; Jean, R.; Mazzio, E.; Badisa, R.; Eyunni, S.; Goodman, C.B.; Redda, K.K.; Soliman, K.F. Substituted Tetrahydroisoquinolines as Microtubule-destabilizing Agents in Triple-Negative Human Breast Cancer Cells. Anticancer Res. 2016, 36, 5043-5052. [CrossRef]

38. Hajek, R. Paclitaxel (Taxol). Cas. Lek. Ces. 1996, 135, 393-396.

39. Paclitaxel and docetaxel in breast and ovarian cancer. Drug Ther. Bull. 1997, 35, 43-46. [CrossRef]

40. Geney, R.; Sun, L.; Pera, P.; Bernacki, R.J.; Xia, S.; Horwitz, S.B.; Simmerling, C.L.; Ojima, I. Use of the tubulin bound paclitaxel conformation for structure-based rational drug design. Chem. Biol. 2005, 12, 339-348. [CrossRef]

41. El-Sahli, S.; Hua, K.; Sulaiman, A.; Chambers, J.; Li, L.; Farah, E.; McGarry, S.; Liu, D.; Zheng, P.; Lee, S.H.; et al. A triple-drug nanotherapy to target breast cancer cells, cancer stem cells, and tumor vasculature. Cell Death Dis. 2021, 12, 8. [CrossRef] [PubMed]

42. Castle, B.T.; McCubbin, S.; Prahl, L.S.; Bernens, J.N.; Sept, D.; Odde, D.J. Mechanisms of kinetic stabilization by the drugs paclitaxel and vinblastine. Mol. Biol. Cell 2017, 28, 1238-1257. [CrossRef] [PubMed]

43. Shi, X.; Sun, X. Regulation of paclitaxel activity by microtubule-associated proteins in cancer chemotherapy. Cancer Chemother. Pharmacol. 2017, 80, 909-917. [CrossRef] [PubMed]

44. Naaz, F.; Haider, M.R.; Shafi, S.; Yar, M.S. Anti-tubulin agents of natural origin: Targeting taxol, vinca, and colchicine binding domains. Eur. J. Med. Chem. 2019, 171, 310-331. [CrossRef] [PubMed]

45. Leung, J.C.; Cassimeris, L. Reorganization of paclitaxel-stabilized microtubule arrays at mitotic entry: Roles of depolymerizing kinesins and severing proteins. Cancer Biol. Ther. 2019, 20, 1337-1347. [CrossRef] [PubMed]

46. Bai, Z.; Liu, X.; Guan, Q.; Ding, N.; Wei, Q.; Tong, B.; Zhao, M.; Zhang, W.; Ma, L. 5-(3,4,5-trimethoxybenzoyl)-4-methyl-2-(p-tolyl) imidazole (BZML) targets tubulin and DNA to induce anticancer activity and overcome multidrug resistance in colorectal cancer cells. Chem. Biol. Interact. 2020, 315, 108886. [CrossRef]

47. Xie, S.; Ogden, A.; Aneja, R.; Zhou, J. Microtubule-Binding Proteins as Promising Biomarkers of Paclitaxel Sensitivity in Cancer Chemotherapy. Med. Res. Rev. 2016, 36, 300-312. [CrossRef] [PubMed]

48. Cao, Y.N.; Zheng, L.L.; Wang, D.; Liang, X.X.; Gao, F.; Zhou, X.L. Recent advances in microtubule-stabilizing agents. Eur. J. Med. Chem. 2018, 143, 806-828. [CrossRef] [PubMed]

49. Li, Y.; Zhou, W.; Tang, K.; Chen, X.; Feng, Z.; Chen, J. Silencing Aurora-A leads to re-sensitization of breast cancer cells to Taxol through downregulation of SRC-mediated ERK and mTOR pathways. Oncol. Rep. 2017, 38, 2011-2022. [CrossRef]

50. Li, Y.; Tang, K.; Zhang, H.; Zhang, Y.; Zhou, W.; Chen, X. Function of Aurora kinase A in Taxol-resistant breast cancer and its correlation with P-gp. Mol. Med. Rep. 2011, 4, 739-746.

51. Habu, T.; Matsumoto, T. p31(comet) inactivates the chemically induced Mad2-dependent spindle assembly checkpoint and leads to resistance to anti-mitotic drugs. Springerplus 2013, 2, 562. [CrossRef] [PubMed]

52. Marcus, A.I.; Peters, U.; Thomas, S.L.; Garrett, S.; Zelnak, A.; Kapoor, T.M.; Giannakakou, P. Mitotic kinesin inhibitors induce mitotic arrest and cell death in Taxol-resistant and -sensitive cancer cells. J. Biol. Chem. 2005, 280, 11569-11577. [CrossRef] [PubMed]

53. Garcia-Escolano, M.; Montoyo-Pujol, Y.G.; Ortiz-Martinez, F.; Ponce, J.J.; Delgado-Garcia, S.; Martin, T.A.; Ballester, H.; Aranda, F.I.; Castellon-Molla, E.; Sempere-Ortells, J.M.; et al. ID1, and ID4 Are Biomarkers of Tumor Aggressiveness and Poor Outcome in Immunophenotypes of Breast Cancer. Cancers 2021, 13, 492. [CrossRef] [PubMed]

54. Zekan, D.S.; Dahman, A.; Hajiran, A.J.; Luchey, A.M.; Chahoud, J.; Spiess, P.E. Prognostic predictors of lymph node metastasis in penile cancer: A systematic review. Int. Braz. J. Urol. 2021, 47, 943-956.

55. Sharma, P.; Patel, D.; Chaudhary, J. Id1 and Id3 expression is associated with increasing grade of prostate cancer: Id 3 preferentially regulates CDKN1B. Cancer Med. 2012, 1, 187-197. [CrossRef]

56. Thankamony, A.P.; Murali, R.; Karthikeyan, N.; Varghese, B.A.; Teo, W.S.; McFarland, A.; Roden, D.L.; Holliday, H.; Konrad, C.V.; Cazet, A.; et al. Targeting the Id1-Kif11 Axis in Triple-Negative Breast Cancer Using Combination Therapy. Biomolecules 2020, 10, 1295. [CrossRef] 
57. Teo, W.S.; Holliday, H.; Karthikeyan, N.; Cazet, A.S.; Roden, D.L.; Harvey, K.; Konrad, C.V.; Murali, R.; Varghese, B.A.; Thankamony, A.P.; et al. Id Proteins Promote a Cancer Stem Cell Phenotype in Mouse Models of Triple-Negative Breast Cancer via Negative Regulation of Robo1. Front. Cell Dev. Biol. 2020, 8, 552. [CrossRef]

58. Tasdemir, N.; Ding, K.; Savariau, L.; Levine, K.M.; Du, T.; Elangovan, A.; Bossart, E.A.; Lee, A.V.; Davidson, N.E.; Oesterreich, S. Proteomic and transcriptomic profiling identifies mediators of anchorage-independent growth and roles of inhibitor of differentiation proteins in invasive lobular carcinoma. Sci. Rep. 2020, 10, 11487. [CrossRef]

59. Wahdan-Alaswad, R.; Harrell, J.C.; Fan, Z.; Edgerton, S.M.; Liu, B.; Thor, A.D. Metformin attenuates transforming growth factor-beta (TGF-beta) mediated oncogenesis in mesenchymal stem-like/claudin-low triple-negative breast cancer. Cell Cycle 2016, 15, 1046-1059. [CrossRef]

60. Castanon, E.; Bosch-Barrera, J.; Lopez, I.; Collado, V.; Moreno, M.; Lopez-Picazo, J.M.; Arbea, L.; Lozano, M.D.; Calvo, A.; Gil-Bazo, I. Id1 and Id3 co-expression correlates with clinical outcome in stage III-N2 non-small cell lung cancer patients treated with definitive chemoradiotherapy. J. Transl. Med. 2013, 11, 13. [CrossRef]

61. Chen, Y.H.; Wu, Z.Q.; Zhao, Y.L.; Si, Y.L.; Guo, M.Z.; Han, W.D. FHL2 inhibits the Id3-promoted proliferation and invasive growth of human MCF-7 breast cancer cells. Chin. Med. J. 2012, 125, 2329-2333. [PubMed]

62. Lin, S.; Mei, W.; Lai, H.; Li, X.; Weng, H.; Xiong, J.; Lin, X.; Zeng, T.; Zhang, Q.; Liu, X.; et al. Cigarette smoking promotes keratinocyte malignancy via generation of cancer stem-like cells. J. Cancer 2021, 12, 1085-1093. [CrossRef] [PubMed]

63. Zhao, Z.; Bo, Z.; Gong, W.; Guo, Y. Inhibitor of Differentiation 1 (Id1) in Cancer and Cancer Therapy. Int. J. Med. Sci. 2020, 17, 995-1005. [CrossRef]

64. O'Brien, C.A.; Kreso, A.; Ryan, P.; Hermans, K.G.; Gibson, L.; Wang, Y.; Tsatsanis, A.; Gallinger, S.; Dick, J.E. ID1, and ID3 regulate the self-renewal capacity of human colon cancer-initiating cells through p21. Cancer Cell 2012, 21, 777-792. [CrossRef]

65. Yang, H.Y.; Liu, H.L.; Liu, G.Y.; Zhu, H.; Meng, Q.W.; Qu, L.D.; Liu, L.X.; Jiang, H.C. Expression and prognostic values of Id-1 and Id-3 in gastric adenocarcinoma. J. Surg. Res. 2011, 167, 258-266. [CrossRef]

66. Shuno, Y.; Tsuno, N.H.; Okaji, Y.; Tsuchiya, T.; Sakurai, D.; Nishikawa, T.; Yoshikawa, N.; Sasaki, K.; Hongo, K.; Tsurita, G.; et al. Id1/Id3 knockdown inhibits metastatic potential of pancreatic cancer. J. Surg. Res. 2010, 161, 76-82. [CrossRef]

67. Cheung, H.W.; Ling, M.T.; Tsao, S.W.; Wong, Y.C.; Wang, X. Id-1-induced Raf/MEK pathway activation is essential for its protective role against taxol-induced apoptosis in nasopharyngeal carcinoma cells. Carcinogenesis 2004, 25, 881-887. [CrossRef]

68. Meng, J.; Liu, K.; Shao, Y.; Feng, X.; Ji, Z.; Chang, B.; Wang, Y.; Xu, L.; Yang, G. ID1 confers cancer cell chemoresistance through STAT3/ATF6-mediated induction of autophagy. Cell Death Dis. 2020, 11, 137. [CrossRef]

69. Liu, K.; Chen, X.; Wu, L.; Chen, S.; Fang, N.; Cai, L.; Jia, J. ID1 mediates resistance to osimertinib in EGFR T790M-positive non-small cell lung cancer through epithelial-mesenchymal transition. BMC Pulm. Med. 2021, 21, 163. [CrossRef]

70. He, Y.; Wei, T.; Ye, Z.; Orme, J.J.; Lin, D.; Sheng, H.; Fazli, L.; Jeffrey Karnes, R.; Jimenez, R.; Wang, L.; et al. A noncanonical AR addiction drives enzalutamide resistance in prostate cancer. Nat. Commun. 2021, 12, 1521. [CrossRef]

71. Kim, H.; Chung, H.; Kim, H.J.; Lee, J.Y.; Oh, M.Y.; Kim, Y.; Kong, G. Id-1 regulates Bcl-2 and Bax expression through p53 and NF-kappaB in MCF-7 breast cancer cells. Breast Cancer Res. Treat. 2008, 112, 287-296. [CrossRef] [PubMed]

72. Mukhopadhyay, C.; Zhao, X.; Maroni, D.; Band, V.; Naramura, M. Distinct effects of EGFR ligands on human mammary epithelial cell differentiation. PLoS ONE 2013, 8, e75907. [CrossRef] [PubMed]

73. Olsen, D.A.; Bechmann, T.; Ostergaard, B.; Wamberg, P.A.; Jakobsen, E.H.; Brandslund, I. Increased concentrations of growth factors and activation of the EGFR system in breast cancer. Clin. Chem. Lab. Med. 2012, 50, 1809-1818. [CrossRef]

74. Peterson, E.A.; Jenkins, E.C.; Lofgren, K.A.; Chandiramani, N.; Liu, H.; Aranda, E.; Barnett, M.; Kenny, P.A. Amphiregulin Is a Critical Downstream Effector of Estrogen Signaling in ERalpha-Positive Breast Cancer. Cancer Res. 2015, 75, 4830-4838. [CrossRef]

75. Schmucker, H.; Blanding, W.M.; Mook, J.M.; Wade, J.F.; Park, J.P.; Kwist, K.; Shah, H.; Booth, B.W. Amphiregulin regulates proliferation and migration of HER2-positive breast cancer cells. Cell Oncol. 2018, 41, 159-168. [CrossRef] [PubMed]

76. Williams, C.B.; Soloff, A.C.; Ethier, S.P.; Yeh, E.S. Perspectives on Epidermal Growth Factor Receptor Regulation in Triple-Negative Breast Cancer: Ligand-Mediated Mechanisms of Receptor Regulation and Potential for Clinical Targeting. Adv. Cancer Res. 2015, 127, 253-281. [PubMed]

77. Kefaloyianni, E.; Keerthi Raja, M.R.; Schumacher, J.; Muthu, M.L.; Krishnadoss, V.; Waikar, S.S.; Herrlich, A. Proximal TubuleDerived Amphiregulin Amplifies and Integrates Profibrotic EGF Receptor Signals in Kidney Fibrosis. J. Am. Soc. Nephrol. 2019, 30, 2370-2383. [CrossRef] [PubMed]

78. Wang, Y.; Jing, Y.; Ding, L.; Zhang, X.; Song, Y.; Chen, S.; Zhao, X.; Huang, X.; Pu, Y.; Wang, Z.; et al. Epiregulin reprograms cancer-associated fibroblasts and facilitates oral squamous cell carcinoma invasion via JAK2-STAT3 pathway. J. Exp. Clin. Cancer Res. 2019, 38, 274. [CrossRef]

79. Rajaram, M.; Li, J.; Egeblad, M.; Powers, R.S. System-wide analysis reveals a complex network of tumor-fibroblast interactions involved in tumorigenicity. PLoS Genet. 2013, 9, e1003789. [CrossRef]

80. Xiang, G.; Liu, F.; Liu, J.; Meng, Q.; Li, N.; Niu, Y. Prognostic role of amphiregulin and the correlation with androgen receptor in invasive breast cancer. Pathol. Res. Pract. 2019, 215, 152414. [CrossRef]

81. Higginbotham, J.N.; Demory Beckler, M.; Gephart, J.D.; Franklin, J.L.; Bogatcheva, G.; Kremers, G.J.; Piston, D.W.; Ayers, G.D.; McConnell, R.E.; Tyska, M.J.; et al. Amphiregulin exosomes increase cancer cell invasion. Curr. Biol. 2011, 21, 779-786. [CrossRef] 
82. Roskoski, R., Jr. The ErbB/HER family of protein-tyrosine kinases and cancer. Pharmacol. Res. 2014, 79, 34-74. [CrossRef]

83. West, N.R. Coordination of Immune-Stroma Crosstalk by IL-6 Family Cytokines. Front. Immunol. 2019, 10, 1093. [CrossRef]

84. Peng, Z.P.; Jiang, Z.Z.; Guo, H.F.; Zhou, M.M.; Huang, Y.F.; Ning, W.R.; Huang, J.H.; Zheng, L.; Wu, Y. Glycolytic activation of monocytes regulates the accumulation and function of neutrophils in human hepatocellular carcinoma. J. Hepatol. 2020, 73, 906-917. [CrossRef]

85. Tanaka, H.; Nishioka, Y.; Yokoyama, Y.; Higashiyama, S.; Matsuura, N.; Matsuura, S.; Hieda, M. Nuclear envelope-localized EGF family protein amphiregulin activates breast cancer cell migration in an EGF-like domain-independent manner. Biochem. Biophys. Res. Commun. 2012, 420, 721-726. [CrossRef]

86. Rego, S.L.; Helms, R.S.; Dreau, D. Tumor necrosis factor-alpha-converting enzyme activities, and tumor-associated macrophages in breast cancer. Immunol. Res. 2014, 58, 87-100. [CrossRef] [PubMed]

87. Taverna, S.; Pucci, M.; Giallombardo, M.; Di Bella, M.A.; Santarpia, M.; Reclusa, P.; Gil-Bazo, I.; Rolfo, C.; Alessandro, R. Amphiregulin contained in NSCLC-exosomes induces osteoclast differentiation through the activation of EGFR pathway. Sci. Rep. 2017, 7, 3170. [CrossRef]

88. Kim, J.W.; Kim, D.K.; Min, A.; Lee, K.H.; Nam, H.J.; Kim, J.H.; Kim, J.S.; Kim, T.Y.; Im, S.A.; Park, I.A. Amphiregulin confers trastuzumab resistance via AKT and ERK activation in HER2-positive breast cancer. J. Cancer Res. Clin. Oncol. 2016, 142, 157-165. [CrossRef]

89. Revillion, F.; Lhotellier, V.; Hornez, L.; Bonneterre, J.; Peyrat, J.P. ErbB/HER ligands in human breast cancer, and relationships with their receptors, the bio-pathological features and prognosis. Ann. Oncol. 2008, 19, 73-80. [CrossRef]

90. Katoh, Y.; Katoh, M. Canonical WNT signaling pathway and human AREG. Int. J. Mol. Med. 2006, 17, 1163-1166. [CrossRef]

91. Nickerson, N.K.; Mill, C.P.; Wu, H.J.; Riese, D.J., 2nd; Foley, J. Autocrine-derived epidermal growth factor receptor ligands contribute to the recruitment of tumor-associated macrophage and growth of basal breast cancer cells in vivo. Oncol. Res. 2013, 20, 303-317. [CrossRef] [PubMed]

92. Riese, D.J., 2nd; Cullum, R.L. Epiregulin: Roles in normal physiology and cancer. Semin. Cell Dev. Biol. 2014, 28, 49-56. [CrossRef] [PubMed]

93. Xia, Q.; Zhou, Y.; Yong, H.; Wang, X.; Zhao, W.; Ding, G.; Zhu, J.; Li, X.; Feng, Z.; Wang, B. Elevated epiregulin expression predicts poor prognosis in gastric cancer. Pathol. Res. Pract. 2019, 215, 873-879. [CrossRef] [PubMed]

94. He, M.; Jin, Q.; Chen, C.; Liu, Y.; Ye, X.; Jiang, Y.; Ji, F.; Qian, H.; Gan, D.; Yue, S.; et al. The miR-186-3p/EREG axis orchestrates tamoxifen resistance and aerobic glycolysis in breast cancer cells. Oncogene 2019, 38, 5551-5565. [CrossRef]

95. Liu, S.; Wang, Y.; Han, Y.; Xia, W.; Zhang, L.; Xu, S.; Ju, H.; Zhang, X.; Ren, G.; Liu, L.; et al. EREG-driven oncogenesis of Head and Neck Squamous Cell Carcinoma exhibits higher sensitivity to Erlotinib therapy. Theranostics 2020, 10, 10589-10605. [CrossRef] [PubMed]

96. Urbaniak, A.; Pina-Oviedo, S.; Yuan, Y.; Huczynski, A.; Chambers, T.C. Limitations of an ex vivo breast cancer model for studying the mechanism of action of the anticancer drug paclitaxel. Eur. J. Pharmacol. 2021, 891, 173780. [CrossRef]

97. Bonnet, J.; Rigal, L.; Mondesert, O.; Morin, R.; Corsaut, G.; Vigneau, M.; Ducommun, B.; Lobjois, V. Mitotic arrest affects clustering of tumor cells. Cell Div. 2021, 16, 2. [CrossRef]

98. Szklarczyk, D.; Franceschini, A.; Kuhn, M.; Simonovic, M.; Roth, A.; Minguez, P.; Doerks, T.; Stark, M.; Muller, J.; Bork, P.; et al. The STRING database in 2011: Functional interaction networks of proteins, globally integrated and scored. Nucleic Acids Res. 2011, 39 (Suppl. 1), D561-D568. [CrossRef]

99. Szklarczyk, D.; Gable, A.L.; Nastou, K.C.; Lyon, D.; Kirsch, R.; Pyysalo, S.; Doncheva, N.T.; Legeay, M.; Fang, T.; Bork, P.; et al. The STRING database in 2021: Customizable protein-protein networks, and functional characterization of user-uploaded gene/measurement sets. Nucleic Acids Res. 2021, 49, D605-D612. [CrossRef] 